\title{
GEOCHEMISTRY AND PETROGENESIS OF METAVOLCANIC ROCKS FROM ARCHAEAN GREENSTONE BELTS: RIO MARIA REGION (SOUTHEAST PARÁ, BRAZIL)
}

\author{
ZORANO SÉRGIO DE SOUZA*, ROBERTO DALL'AGNOL**, CLAUDINEI GOUVEIA DE OLIVEIRA*** \&

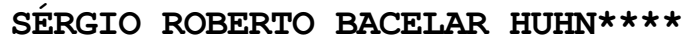

\begin{abstract}
RESUMO GEQQUIMMICA EPETROGÊNESEDEROCHASMETAVULCÂNICASDE GREENSTONE BELTS AROUEANOS: REGIAOO DE RIO MARIA (SUDESTE DO PARÁ, BRASIL) A região de Rio Maria, situada a cerca de $250 \mathrm{~km}$ a sul da Serra dos Carajás, compõe um típico terreno granito - greenstone arqueano bem preservado e com idade superior a $2,87 \mathrm{Ga}$. As seqüências supracrustais apresentam rochas meta-ultramáficas (UM -talco-tremolita xistos com texturas spinifex) na base, seguidas por metabásicas $(\boldsymbol{B} \boldsymbol{A S}$ - basaltos maciços com texturas de resfriamento rápido; $\boldsymbol{G B}$ - gabros porfiríticos) e, no topo, metadacitos $(\boldsymbol{D} \boldsymbol{A C}$ ) porfiríticos, com fenocristais de plagioclásio, quartzo, hornblenda e titanita. Metassedimentos terrígenos (grauvacas, siltitos) e vulcano-químicos (cherts, formações ferríferas) se intercalam nas porções basais a intermediárias. Três séries geoquímicas são reconhecidas: komatiítica $(\boldsymbol{U M})$, toleítica de baixo potássio $(\boldsymbol{B} \boldsymbol{A} \boldsymbol{S}, \boldsymbol{G B})$ e cálcico-alcalina sódica $(\boldsymbol{D} \boldsymbol{A C})$. Estas séries evoluíram essencialmente por mecanismos de cristalização fracionada a baixas pressões, com os respectivos cumulados contendo olivina + ortopiroxênio, clinopiroxênio + plagioclásio e plagioclásio + quartzo + feldspato potássico + hornblenda + biotita + titanita. Modelamento de óxidos e elementos terras raras sugere fontes mantélicas para os komatiitos e tolétos, gerados por 10 a $25 \%$ de fusão parcial de lherzolito com 1 a $5 \%$ de granada. Já o vulcanismo dacítico requer a fusão parcial ( 10 a $15 \%)$ de toleíto transformado em granada anfibolito, deixando um resíduo com hornblenda, plagioclásio, clinopiroxênio e granada. Os tipos de fontes envolvidas e as características de elementos traços sugerem bacias marginais e arcos insulares para a evolução dos greenstone belts, sendo que o magmatismo cálcico-alcalino (vulcanismo há $c a$. 2,97-2,90 Ga e plutonismo há $c a .2,87 \mathrm{Ga}$ ) representaria a etapa final de estabilização tectônica e soldamento de blocos nesta região, formando a crosta continental que serviu de embasamento para as unidades neoarqueanas da porção norte da Província Mineral de Carajás.
\end{abstract}

Palavras-chave: vulcanismo, petrologia, gênese de magmas, evolução geodinâmica.

ABSTRACT The Rio Maria region, located at about $250 \mathrm{~km}$ south of the Carajás Ridge, is a well preserved typical Archaean ( $>2.87 \mathrm{Ga}$ ) granite - greenstone terrane. Supracrustal sequences are made up of meta-ultramafic rocks $(\boldsymbol{U M}$ - talc-tremolite schists with relict spinifex textures) at the base, followed by metabasic rocks $(\boldsymbol{B} \boldsymbol{A} \boldsymbol{S}$ - massif basalts with quenched textures; $\boldsymbol{G B}$ - porphyritic gabbros) and, at the top, metadacitic rocks (DAC) with plagioclase quartz, hornblende and sphene phenocrysts. Terrigenous (graywackes, siltstones) and volcano-chemical metasediments (cherts, iron formations) are intercalated within the basal and intermediate stratigraphic levels. The volcanic rocks define three geochemical series, namely komatiite $(\boldsymbol{U M})$, low-K tholeite $(\mathbf{B A S}, \boldsymbol{G B})$ and sodic calc-alkaline $(\boldsymbol{D} \boldsymbol{A C})$. These series mainly evolved by low pressure fractional crystallization giving respectively olivine + orthopyroxene, clinopyroxene + plagioclase and plagioclase + quartz + alkali feldspar + hornblende + biotite + sphene cumulates. Modeling based on major and REE indicate a Iherzolitic source with 1-5\% garnet; the degree of partial melting is from 10 to $25 \%$ in order to generate the komatiitic and tholeiitic magmas. The source of dacitic volcanism could be a metasomatised tholeiitic crust transformed into garnet arnphibolite, melted from 10 to $15 \%$ and leaving a residue with hornblende, plagioclase, garnet and clinopyroxene. The source types and the trace elements characteristics allow to consider that the magma generated in marginal basins and island arcs geodynamic environments. Consequently, the calc-alkaline magmatism (volcanism at $c a .2 .97-2.90 \mathrm{Ga}$ and plutonism at $c a .2 .87$ $\mathrm{Ga}$ ) would represent a stage of tectonic stabilization and welding of crustal blocks, forming the continental crust which acted as cratonic basement for the Neoarchaean evolution of the northern portion of the Carajás Mineral Province.

Key words: volcanism, petrology, magma genesis, geodynamic evolution.

INTRODUCTION The Rio Maria granite - greenstone terrane (RMGGT) is located in the southeast of Pará State, northern Brazil, between $45^{\circ} 45^{\prime} \mathrm{W}$ and $51^{\circ} \mathrm{W}$ and $6^{\circ} 45^{\prime} \mathrm{S}$ and $8^{\circ} \mathrm{S}$ (Figure 1). It occurs on the southern part of the Carajás Mineral Province, and reached its tectonic stabilization at the end of the Mesoarchaean (Souza et al 1996). The understanding of the regional geological evolution has been improved during the last decade (Docegeo 1988, Souza et al. 1990, 1996, Macambira \& Lafon 1995, Althoff et al. 1995, Costa et al. 1995, Dall'Agnol et al 1996).

The greenstone belts of the $\boldsymbol{R M G G T}$ belong to the Andorinhas Supergroup (Docegeo 1988, Huhn et al. 1988), which includes several volcano-sedimentary sequences (Sapucaia, Identidade, Lagoa Seca, Babaçu, Seringa) (Figure 1). This supergroup consists of the Babaçu (at the base) and Lagoa Seca (at the top) groups. The former is composed of meta-ultramafic (komatiites) and metamafic (basalts and gabbros) rocks, whereas in the other group felsic to intermediate rocks, with intercalations of terrigenous sediments (metagraywackes and metasiltstones) dominate. All these rocks are intruded at ca. $2.87 \mathrm{Ga}$ by Archaean metagranitoids, as well as by anoro.genic Paleoproterozoic (ca. 1.9 Ga) granites (Huhn et al. 1988, Souza et al. 1990, Souza 1994, Oliveira et al. 1995, Souza \& Dall'Agnol 1995a, Dall'Agnol et al. 1996). The gold bearing greenstone belts (Cordeiro 1982, Nascimento \& Biagini 1988, Oliveira \& Leonardos 1990) have been metamorphosed in greenschist to arnphibolite facies conditions (Oliveira 1993, Souza \& Dall'Agnol 1994,1996). They are WNW-ESE elongated and their structural patterns were interpreted as resulting from dextral transpression (Souza et al. 1988, Souza 1994, Souza \& Dall'Agnol 1995a, Souza et al. 1996). The metagranitoids have a laccolithic shape and have been emplaced in high crustal level, thus inducing contact metamorphism in the greenstone belts (Souza et al. 1992b, Souza 1994, Souza \& Dall'Agnol 1995b).

\footnotetext{
* Departamento de Geologia - CCE / UFRN; Caixa Postal 1502, CEP 59072-970 Natal / RN, Fax: (084)215.37.82; e-mail zorano@geologia.ufrn.br ** Centro de Geociências / UFPA; Caixa Postal 1611, CEP 66075-900 Belém / PA, Fax: (091)211.16.09

*** Instituto de Geociências / UnB - Campus Darcy Ribeiro - Asa Norte - Fax: (061)347.40.62; e-mail gouveia@guarany.cpd.unb.br

**** Rio Doce Geologia e Mineração S.A. - Docegeo - Travessa Lomas Valentinas, 2717 - Marco, CEP 66095-770 Belém / PA, Fax: (091)226.49.35
} 
(a)

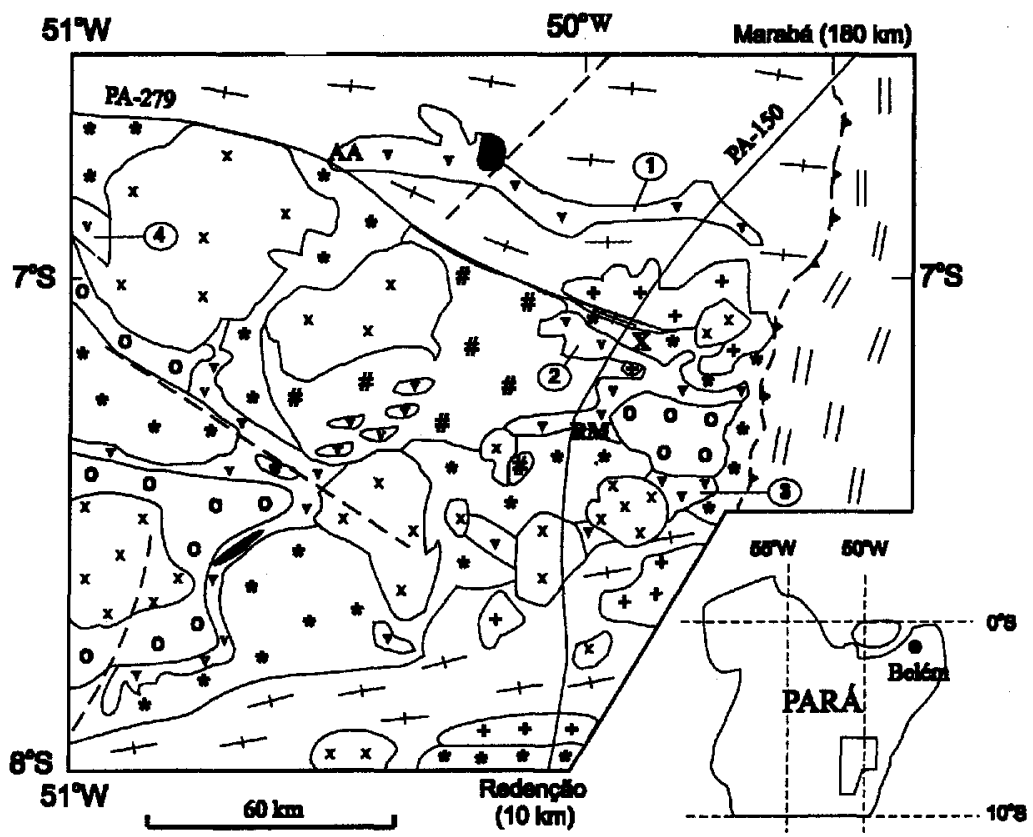

(b)

II Araguaia Folded Belt (Brasillano Cycle)

X Anorogenic Granites (1.9 Ga)

o Rio Fresco Group / Aquas Claras Formation (2.76 - $2.6 \mathrm{Ga})$

Calc-Alkaline Granitoids (2.87 Ga) + Granites \# Trondhjemites * Granodlorites

v Greenstone Belts (Andorinhas Supergroup)

(1) Sapucala belt (2) Identidade belt

(3) Lagoa Seca / Babagu Belts (4) Seringa belt

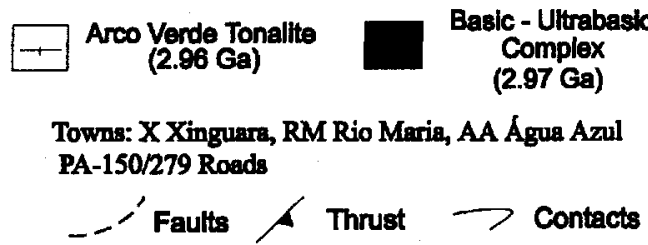

Figure 1 - Geological map (a) and respective legend (b) of the granite - greenstone terrane of the Rio Maria region, based on Huhn et al (1988), Costa et al. (1995) and Dall'Agnol et al. (unpublished).

Figura 1 - Mapa geológico (a) e respectiva legenda (b) do terreno granito - greenstone da região de Rio Maria, baseado em Huhn et al (1988), Costa et al. (1995) and Dall'Agnol et al (inédito).

The Andorinhas Supergroup is older than the intrusive metaplutonic rocks dated at $2.87 \mathrm{Ga}$ (U-Pb zircon, Macambira 1992, Pimentel \& Machado 1994). The Arco Verde Tonalite (Althoff et al. 1995) aged of $2.96 \mathrm{Ga}$ (U-Pb zircon, Macambira 1992), could be correlated with the felsic volcanism of the greenstone belts, this one aged of 2.97 to $2.90 \mathrm{Ga}$ (U-Pb zircon, Macambira 1992, Pimentel \& Machado 1994). Others units of the region include: basic to ultrabasic layered complexes, one of them located in Serra Azul area (at the SW of Figure 1) and dated at ca. $2.97 \mathrm{Ga}$ (U-Pb zircon, Pimentel \& Machado 1994), pjataformal covers of the Rio Fresco Group correlated to the Aguas Claras Formation (2.76 to $2.65 \mathrm{Ga}$, single zircon $\mathrm{Pb}-\mathrm{Pb}$, Dias et al. 1996) at the Carajás Ridge, several granitic anorogenic plutons $(1,9 \mathrm{Ga}, \mathrm{U}-\mathrm{Pb}$ zircon, Machado et al. 1991, Dall'Agnol et al. 1994), and the Araguaia Folded Belt (Brasiliano Cycle).

Geographic distribution, lithostratigraphic relationships and structural patterns of the greenstone belts of the Rio Maria region are reasonably well known (Cordeiro 1982, Docegeo 1988, Huhn et al. 1988, Souza et al. 1988, 1990). However, their geochemistry has been less studied (Gama Jr. et al. 1982 and Huhn 1992 in the Babaçu belt, Huhn et al. 1986 in the Seringa belt, Nascimento \& Biagini 1988 in the Lagoa Seca belt, Souza 1994 and Souza \& Dall'Agnol 1995c, in press, in the Identidade belt). Consequently the purpose of this paper is to summarize and synthetise all the available geochemical data in order to obtain a better characterization and interpretation of the petrogenetic evolution of these volcanic series.

PETROGRAPHY The mineralogy of the metavolcanic rocks was strongly modified, mainly in ultramafic and mafic facies. In ductile shear zones the rocks were transformed into mylonites (Souza \& Dall'Agnol 1995d) which frequently acted as hydrotermal channel where sulfide and gold concentrated (Cordeiro 1982, Nascimento \& Biagini 1988,
Huhn 1992, Oliveira 1993). However in low strain places few igneous structures and textures were preserved: basaltic pillow lavas in the Identidade belt (Docegeo 1988, Souza et al. 1988), spinifex and cumulate textures in komatiitic lavas of the Seringa belt (Huhn et al. 1986), and porphyritic texture in felsic rocks from the Identidade (Souza \& Dall'Agnol in press) and Sapucaia belts (Oliveira 1987, Oliveira \& Leonardos 1990). According to petrographical, textural and geochemical characteristics, the volcanic rocks can be classified as ultramafics (UM), mafics (basalts - BAS and gabbros - $\boldsymbol{G B})$ and felsics $(\boldsymbol{D} \boldsymbol{A C})$, as described below.

The $U M$ rocks are tremolite schists and talc-tremolite schists where strongly elongated to acicular amphibole is more abundant than chlorite and talc. These minerals formed a talc- and chlorite-bearing fine grained matrix and show relicts of spinifex textures mainly in the Seringa belt (Huhn et al. 1986). The amphibole of the Identidade belt is tschermakitic in composition with $\mathrm{mg \# <}<0.45$ and $\mathrm{Si}<6.35$ (Souza \& Dall'Agnol 1996). In the Seringa belt, Huhn et al. (1986) described a succession of mafic to ultramafic flows, in which they distinguished three zones: 1) cumulates at the base; 2) medium to coarse grained facies with abundant spinifex textures; and 3) fine-grained rocks with chilled and fractured margins and breccia pockets, at the top.

The more preserved mafic rocks are situated in the Identidade (Souza \& Dall'Agnol 1995c) and Sapucaia belts (Oliveira \& Leonardos 1990). The $\boldsymbol{B} \boldsymbol{A S}$ shows different degrees of recrystallization, but still with relicts of hyalophitic and pilotaxitic textures. The $\boldsymbol{G B}$ are fine to medium grained, in some cases with plagioclase phenocrysts (andesine). $\boldsymbol{B} \boldsymbol{A S}$ and $\boldsymbol{G} \boldsymbol{B}$ only differ by their relative mineral proportions. Both contain green to blue amphibole, epidote, plagioclase (albite, andesine), sphene, and subordinated amounts of green chlorite, quartz and biotite. The amphibole has $\mathrm{mg} \#>0.55$ and $\mathrm{Si}>7.15$ and is classified as transitional from actinolite to 
Mg-hornblende in the $\boldsymbol{B} \boldsymbol{A} \boldsymbol{S}$ or as actinolite in the $\boldsymbol{G B}$ (Souza \& Dall'Agnol 1996).

Fresh felsic volcanic rocks outcrop in the Identidade belt, and are also found in boreholes in the Sapucaia belt (Oliveira 1987, Oliveira \& Leonardos 1990). They correspond to porphyritic metadacites, showing quartz phenocrysts with resorption rim, frequently saussuritized tabular plagioclase (oligoclase), prismatic or acicular green hornblende phenocrysts, together with subordinated amounts of sphene and apatite microphenocrysts. The groundmass is very fine- to fine- or medium-grained and with granophyric intergrowths. The less evolved fades are richer in hornblende and sphene phenocrysts as well as in mafic clots (hornblende \pm biotite \pm sphene \pm epidote), and impoverished in quartz and granophyric intergrowths with regard to the more evolved ones. The preferential orientation of laths and microliths of plagioclase in the groundmass forms pilotaxitic- or trachytoid-like textures. The presence of hydrous phases of magmatic origin such as hornblende, biotite and apatite demonstrates that the dacitic magma was rich in volatiles.

\section{GEOCHEMICAL CHARACTERIZATION AND PET- ROGENETIC EVOLUTION Analytical Methods}

One part of the samples has been analyzed by Geosol (Babaçu / Lagoa Seca belts - Nascimento \& Biagini 1988, Huhn 1992; Sapucaia belt - Oliveira \& Leonardos 1990; Seringa belt -Huhn et al. 1986), and the others at the Centro de Geociências of UFPA (Babaçu - Gama Jr. et al 1982, and Identidade belts - Souza 1994) and CRPG / Nancy (Identidade belt - Souza 1994). In Geosol and Centro de Geociências (UFPA) most of the elements was analyzed by the X-ray fluorescence method $\left(\mathrm{SiO}_{2}, \mathrm{Al}_{2} \mathrm{O}_{3}, \mathrm{Fe}_{2} \mathrm{O}_{3}\right.$ t $, \mathrm{CaO}, \mathrm{K}_{2} \mathrm{O}, \mathrm{TiO}_{2}, \mathrm{P}_{2} \mathrm{O}_{5}, \mathrm{Ba}, \mathrm{Sr}, \mathrm{Rb}, \mathrm{Nb}$, $\mathrm{Y}, \mathrm{Zr})$ and others $\left(\mathrm{MgO}, \mathrm{MnO}, \mathrm{Na}_{2} \mathrm{O}, \mathrm{Ni}, \mathrm{Cr}\right)$ by atomic absorption. At CRPG the above mentioned elements plus rare earths, Sc, Co, V, U and Th were analyzed by inductively coupled plasma atomic emission spectrometry (ICP-AES). The amount of $\mathrm{FeO}$ was calculated by wet methods and the total volatiles by loss on ignition $\left(\mathrm{T}=900^{\circ} \mathrm{C}\right)$. The analytical errors are less than $5 \%$ for major oxides, less than $10 \%$ for the minor ones, and less than $5 \%$ for the trace elements. Table 1 shows the averages of chemical analyses for the greenstone belts discussed in the text. The analytical data referred in this section can be seen in the authors cited above. In the diagrams discussed below all the analyses were normalized to $100 \%$ on a volatile-free basis (Figure 2).

Definition of Geochemical Series In the present work, only data from the undeformed regions are discussed, consequently samples near or inside shear zones were not included here. Even in these supposed preserved areas, the scattering of some samples in diagrams with $\mathrm{Na}_{2} \mathrm{O}, \mathrm{CaO}, \mathrm{K}_{2} \mathrm{O}$ and $\mathrm{Al}_{2} \mathrm{O}_{3}$ can be correlated to signs of alteration seen in thin sections, such as sassuritization of plagioclase, chloritization of biotite and amphibole, formation of secondary pyrite, hematite, tourmaline and carbonate. This kind of alteration is best seen in metakomatiites of Lagoa Seca (Nascimento \& Biagini 1988) and Sapucaia belts (Oliveira \& Leonardos 1990) where chloritization and carbonatization are common. In this case even the LREE, as well as $\mathrm{Zr}, \mathrm{Nb}$, Ti and $\mathrm{Y}$ can be mobilized to varying degrees as has been clearly demonstrated in others basaltic and komatiitic flows over the world (Brewer \& Atkin 1989, Tourpin et al. 1991, Lahaye \& Arndt 1996).

Major and trace elements relationships show that the volcanic rocks of the greenstone belts can be separated in three distinct geochemical series, in accordance to previous petrographic studies.

The $\boldsymbol{U} \boldsymbol{M}$ are classified as pyroxenitic komatiites (Figures $2 \mathrm{a}, 2 \mathrm{~b})$, impoverished in alkalis $\left(\mathrm{Na}_{2} \mathrm{O}+\mathrm{K}_{2} \mathrm{O} 0.5 \%\right.$, and $\mathrm{K}_{2} \mathrm{O}$
$0.1 \%$ ), and with $\mathrm{TiO}_{2}<0.9 \%$. The $m g \#$ values varies between 0.67 and 0.86 , with those richer in magnesium from the Sapucaia belt, and the poorer ones from the Lagoa Seca belt. They follow a differentiation trend similar to that found in greenstone belts of Munro, Geluk and Finland, but very contrasted with regard to the Barberton greenstone belt (Figure $2 \mathrm{~b}$ ). Compared to the associated tholeiites, the $\boldsymbol{U} \boldsymbol{M}$ are $\mathrm{Cr}$, Ni and $\mathrm{Co}$ richer with higher $\mathrm{CaO} / \mathrm{TiO}_{2}, \mathrm{Al}_{2} \mathrm{O}_{3} / \mathrm{TiO}_{2}$ and $\mathrm{Y} / \mathrm{Zr}$, and lower $\mathrm{Sc}, \mathrm{Rb}, \mathrm{Sr}, \mathrm{Ba}$ and $\mathrm{Zr}$. Variation diagrams (Figure $3)$ exemplify the high $m g \#(0,6), \mathrm{Cr}(500-4000 \mathrm{ppm})$ and $\mathrm{Ni}$ (300-1286 ppm), and low $\mathrm{Al}_{2} \mathrm{O}_{3}, \mathrm{CaO}, \mathrm{TiO}_{2}$ and $\mathrm{SiO}_{2}$, with the exception of some samples from the Lagoa Seca belt. $\mathrm{K}_{2} \mathrm{O}$, $\mathrm{Ba}, \mathrm{Nb}$ and $\mathrm{Rb}$ are very low, usually below the detection limits of analytical methods.

Metabasic rocks were separated into basaltic $(\boldsymbol{B} A \boldsymbol{S})$ and gabbroic $(\boldsymbol{G B})$ types in the Identidade belt, they follow a low-K tholeiitic trend (Figures $2 \mathrm{a}, 2 \mathrm{c}$ ), with $\mathrm{K}_{2} \mathrm{O} / \mathrm{Na}_{2} \mathrm{O}$ from 0.05 to 0.29 . The $\boldsymbol{G} \boldsymbol{B}$ of the Identidade belt are $\mathrm{Fe}+\mathrm{Ti}$ enriched when compared to the $\boldsymbol{B} \boldsymbol{A S}$ (Figure 2a). Some samples of metabasalts of the Lagoa Seca belt are alkalis enriched (Figure 2c). With regard to $\boldsymbol{U} \boldsymbol{M}$, the tholeiites have higher AhOs and $\mathrm{TiO}_{2}$ (Figure 3), V (237-311 ppm) and $\mathrm{Y}(19-28 \mathrm{ppm})$, and lesser $m g \#$ (Figure 3), $\mathrm{Cr}(148-393 \mathrm{ppm})$ and $\mathrm{Ni}(89-156 \mathrm{ppm})$ (Figure 3). Their $\mathrm{K}_{2} \mathrm{O} / \mathrm{Na}_{2} \mathrm{O}$ ratios are lower than 0.3 , $\mathrm{AbO} 3<16 \%$ and normative quartz $<5 \%$. The contents of major and minor oxides indicate similarities between $\boldsymbol{B} \boldsymbol{A} \boldsymbol{S}$ and $\boldsymbol{G B}$ and depleted Archaean tholeiites (77/7) as defined by Condie (1981). $\boldsymbol{B} \boldsymbol{A} \boldsymbol{S}$ and $\boldsymbol{G} \boldsymbol{B}$ are distinguished from Mg-basalts described by Arndt et al (1977) and Arndt \& Nisbet (1982) because of their greater TIUU2 $(>0,7 \mathrm{wt} \%), \mathrm{Al}_{2} \mathrm{O}_{5}(>12 \mathrm{wt} \%)$, $\mathrm{K}_{2} \mathrm{O}(>0,15$ wt $\%)$ and $\mathrm{P}_{2} \mathrm{O}_{5}(>0,09$ wt $\%)$, and lower $\mathrm{MgO}$ $(<9$ wt \%).

The $\boldsymbol{D} \boldsymbol{A C}$ are dacitic to rhyolitic in composition, with $\mathrm{SiO} 2$ ranging from $61 \%$ to $75 \%$. Samples from the Sapucaia belt do not follow the characteristic trend of the other metavolcanic rocks (Figure 4). This is probably due to hydrothermal changes suffered by these rocks, which resulted in $\mathrm{K}_{2} \mathrm{O}$ or $\mathrm{MgO}$ enrichment, and $\mathrm{SiO}_{2}$ impoverishment (Oliveira 1987, Oliveira \& Leonardos 1990). The $\boldsymbol{D A C}$ are calc-alkaline and follow the sodium (trondhjemitic) differentiation trend in a K-Na-Ca cationic diagram (Figure 4). They are clearly distinguished from $\boldsymbol{U} \boldsymbol{M}$ and $\boldsymbol{B} \boldsymbol{A} \boldsymbol{S} / \boldsymbol{G B}$ for having greater $\mathrm{SiO} 2$ and $\mathrm{Al}_{2} \mathrm{O}_{3}$ (Figure 3), as well as alkalis, $\mathrm{Ba}(464-1313 \mathrm{ppm}), \mathrm{Rb}$ (42-103 ppm), Sr (295-633 ppm), Zr (71-167 ppm) and U $(0.63-2.13 \mathrm{ppm})$, and lesser FeOt, $\mathrm{Cr}(12-66 \mathrm{ppm})$ and $\mathrm{Ni}$ (9-36 ppm) (Figure 3), besides the lowest V (12-61 ppm) and Co $(\mathrm{ppm})$.

The rare earth elements (REE) from de Identidade (data from Souza 1994, and Souza \& Dall'Agnol 1995c, in press) and Seringa (data from Huhn et al 1986) belts are discussed below. In Seringa belt the patterns are more preserved, showing a slight light REE (LREE) enrichment, with $(\mathrm{La} / \mathrm{Sm}) \mathrm{N}$ from 1.3 to $5.7,(\mathrm{Gd} / \mathrm{Yb}) \mathrm{N}$ from 0.9 to 1.6 and $\mathrm{Eu}$ anomaly $\left(\mathrm{Eu} / \mathrm{Eu}^{*}\right)$ from 0.5 to 0.7 . In Identidade belt, LREE (mainly $\mathrm{Ce}, \mathrm{Nd}, \mathrm{Sm}$ ) and $\mathrm{Eu}$ anomalies (as low as 0.18 ) are somewhat irregular, suggesting their modification by post-eruptive alteration. Heavy REE (HREE) are very well preserved with $(\mathrm{Gd} / \mathrm{Yb}) \mathrm{N}$ ratios from 1 to 2.3 . The tholeiites have more regular patterns and are alike to the TH1 depleted tholeiites of Condie (1981). They are characterized by $(\mathrm{La} / \mathrm{Yb}) \mathrm{N}=1.2-1.6$, $(\mathrm{La} / \mathrm{Sm})_{\mathrm{N}}=0.9-1.2,(\mathrm{Gd} / \mathrm{Yb})_{\mathrm{N}}=1.1-1.3$ and $\mathrm{Eu} / \mathrm{Eu} *=0.74-$ 0.98 . Concerning the $\boldsymbol{D} \boldsymbol{A C}$, their patterns are strongly fractionated and HREE-impoverished $\left(\mathrm{Yb}_{\mathrm{N}}\right)$, with LREE enrichment $\left((\mathrm{La} / \mathrm{Yb})_{\mathrm{N}}=10.7-39.5\right)$ and virtually no significant $\mathrm{Eu}$ anomaly $\left(\mathrm{Eu} / \mathrm{Eu}^{*}=0.88-1.04\right)$.

Petrogenesis Textural observations such as zoned plagioclase and relicts of clinopyroxene phenocrysts in the basic rocks and zoned plagioclase, amphibole, sphene, apatite and 
Table l-Average chemical compositions of metavolcanic rocks of greenstone belts from Rio Maria region, southeastern Pará State, Brazil.

Tabela 1 - Composições químicas médias de rochas metavulcânicas de greenstone belts da região de Rio Maria, sudeste do Estado do Pará, Brasil.

\begin{tabular}{|c|c|c|c|c|c|c|c|c|c|c|c|}
\hline & \multicolumn{4}{|c|}{ Komatiites } & \multicolumn{5}{|c|}{ Thopeiites } & \multicolumn{2}{|c|}{ Dacites } \\
\hline & IDT $^{(1)}$ & SER $^{(2)}$ & $\mathrm{SAP}^{(3)}$ & $\mathrm{LS}^{(4)}$ & \multicolumn{2}{|c|}{$\mathrm{IDT}^{(1)}$} & $\mathrm{BB}^{(5)}$ & $\mathrm{BB}^{(6)}$ & $\mathrm{LS}^{(4)}$ & IDT $^{(7)}$ & $\mathrm{SAP}^{(3)}$ \\
\hline & & & & & Basaits & Gabbros & Basalts & Basalts & Basalts & & \\
\hline & $\mathrm{N}=3$ & $\mathrm{~N}=6$ & $\mathrm{~N}=6$ & $\mathrm{~N}=3$ & $\mathrm{~N}=7$ & $\mathrm{~N}=4$ & $\mathrm{~N}=7$ & $\mathrm{~N}=5$ & $N=4$ & $\mathrm{~N}=10^{*}$ & $\mathrm{~N}=4$ \\
\hline $\mathrm{SiO}_{2}(\mathrm{wt} \%)$ & 49,56 & 47,36 & 45,2 & 50,9 & 49,39 & 49,98 & 56,02 & 51,37 & 51,27 & 70,91 & 70,28 \\
\hline $\mathrm{TiO}_{2}$ & 0,23 & 0,38 & 0,22 & 0,64 & 0,82 & 0,95 & 1,44 & 1,59 & 0,8 & 0,26 & 0,3 \\
\hline $\mathrm{Al}_{2} \mathrm{O}_{3}$ & 7,77 & 8,13 & 10,24 & 4,17 & 15,76 & 15,15 & 15,14 & 15,07 & 10,07 & 15,82 & 17,1 \\
\hline $\mathrm{FeOt}$ & 11,1 & 12,83 & 10,54 & 14,9 & 11,85 & 13,57 & 10,25 & 13,32 & 15,97 & 2,12 & 3,15 \\
\hline $\mathrm{MnO}$ & 0,15 & 0,32 & 0,2 & 0,13 & 0,2 & 0,23 & 0,26 & 0,21 & 0,15 & 0,03 & 0,05 \\
\hline $\mathrm{MgO}$ & 25,58 & 21,75 & 23,94 & 18,98 & 8,05 & 6,94 & 6,02 & 5,04 & 11,24 & 0,93 & 1,75 \\
\hline $\mathrm{CaO}$ & 5,45 & 8,74 & 9,26 & 8,01 & 11,7 & 11,08 & 6,55 & 11,17 & 7,02 & 2,2 & 2,25 \\
\hline $\mathrm{Na}_{2} \mathrm{O}$ & 0,03 & 0,39 & 0,3 & 0,09 & 1,81 & 1,76 & 3,69 & 1,97 & 0,12 & 5,29 & 2,65 \\
\hline $\mathrm{K}_{2} \mathrm{O}$ & 0 & 0,06 & 0,02 & 2,12 & 0,24 & 0,15 & 0,55 & 0,26 & 3,3 & 2,31 & 2,35 \\
\hline $\mathrm{P}_{2} \mathrm{O}_{5}$ & 0,13 & 0,04 & 0,08 & 0,06 & 0,18 & 0,19 & 0,08 & - & 0,06 & 0,13 & 0,12 \\
\hline Total & 100 & 100 & 100 & 100 & 100 & 100 & 100 & 100 & 100 & 100 & 100 \\
\hline$m g \#$ & 0,81 & 0,75 & 0,8 & 0,69 & 0,55 & 0,47 & 0,52 & 0,46 & 0,51 & 0,44 & 0,49 \\
\hline $\mathrm{CaO} / \mathrm{Al}_{2} \mathrm{O}_{3}$ & 0.00 & 0.01 & 0.00 & 0.02 & 0.00 & 0.00 & 000. & 0.00 & 0.00 & 000. & 000. \\
\hline $\mathrm{Al}_{2} \mathrm{O}_{3} / \mathrm{TiO}_{2}$ & 03.4 & 02.1 & 04.7 & 0.07 & 01.9 & 01.6 & 01.1 & 0.09 & 01.3 & 06.1 & 05.7 \\
\hline $\mathrm{CaO} / \mathrm{TiO}_{2}$ & 02.4 & 02.3 & 04.2 & 01.3 & 01.4 & 01.2 & 0.05 & 0.07 & 0.09 & 0.08 & 0.08 \\
\hline $\mathrm{V}(\mathrm{ppm})$ & 124 & 222 & - & - & 226 & 292 & - & - & - & 31 & - \\
\hline $\mathrm{Cr}$ & 2574 & 3227 & 1595 & 524 & 297 & 213 & - & - & - & 31 & 50 \\
\hline Co & 88 & 136 & 91 & - & 53 & 56 & - & - & - & 12 & 92 \\
\hline $\mathrm{Ni}$ & 994 & 59 & 67 & 1017 & 146 & 110 & - & - & - & 17 & 25 \\
\hline$Y$ & 14 & 15 & - & - & 22 & 25 & - & - & - & $<8$ & - \\
\hline $\mathrm{Zr}$ & 15 & 45 & - & - & 48 & 59 & - & - & - & 106 & - \\
\hline $\mathrm{Y} / \mathrm{Zr}$ & 0.00 & 000. & - & - & 000. & 000. & - & - & - & $<0,08$ & - \\
\hline $\mathrm{La}(\mathrm{ppm})$ & 11,95 & 4,75 & - & - & 3,66 & 4,47 & - & - & - & 12,87 & - \\
\hline $\mathrm{Ce}$ & 9,79 & 9,22 & - & - & 13,26 & 17,06 & - & - & - & 27,3 & - \\
\hline Nd & 8,83 & 4,05 & - & - & 5,92 & 6,94 & - & - & - & 11,2 & - \\
\hline $\mathrm{Sm}$ & 2,59 & 1,78 & - & - & 2,25 & 2,59 & - & - & - & 2,08 & - \\
\hline Eu & 0,37 & 0,35 & - & - & 0,72 & 0,8 & - & - & - & 0,54 & - \\
\hline Gd & 1,9 & 1,25 & - & - & 2,58 & 2,92 & - & - & - & 1,4 & - \\
\hline Dy & 1,64 & 1,03 & - & - & 3,13 & 3,52 & - & - & - & 0,86 & - \\
\hline $\mathrm{Er}$ & 0,98 & 1,13 & - & - & 1,89 & 2,13 & - & - & - & 0,46 & - \\
\hline $\mathrm{Yb}$ & 0,88 & 1,13 & - & - & 1,84 & 2,08 & - & - & - & 0,36 & - \\
\hline $\mathrm{Lu}$ & 0,12 & 2,45 & - & - & 0,25 & 0,31 & - & - & - & 0,07 & - \\
\hline$\Sigma$ REE & 39,05 & 27,14 & - & - & 35,5 & 42,82 & - & - & - & 57,14 & - \\
\hline$(\mathrm{La}-\mathrm{Sm})_{\mathrm{N}}$ & 1,8 & 2,38 & - & - & 1 & 1,05 & - & - & - & 3,77 & - \\
\hline$(G d-Y b)_{N}$ & 1,73 & 1,15 & - & - & 1,14 & 1,15 & - & - & - & 3,12 & - \\
\hline$(\mathrm{La}-\mathrm{Yb})_{\mathrm{N}}$ & 7,23 & 2,85 & - & - & 1,32 & 2,02 & - & - & - & 23,61 & - \\
\hline $\mathrm{Eu}^{*}$ & 0,36 & 0,67 & - & - & 0,92 & 0,9 & - & - & - & 0,92 & - \\
\hline
\end{tabular}

* N=4 for Rare Elements. Greenstone belts: IDT Identidade, SER Seringa, SAP Sapucaia, LS Lagoa Seca, BB Babaçu.

${ }^{(1)}$ Souza \& Dall'Agnol (1995c); ${ }^{(2)}$ Huhn et al. $(1986) ;{ }^{(3)}$ Oliveira $(1987) ;{ }^{(4)}$ Nascimento \& Biagini (1988); ${ }^{(5)}$ Huhn (1992);

${ }^{(6)}$ Gama Jr. et al. (1982), ${ }^{(7)}$ Souza \& Dall'Agnol (in press).

re-absorbed quartz phenocrysts in the dacitic rocks suggests that some kind of fractional crystallization mechanism has played some role in the evolution of these volcanic series. Compatible $v s$. incompatible behaviors for trace elements, and calculated cumulates all suggest fractional crystallization as the main mechanism of evolution for the three magmatic series described above. Because of the irregularity of some trace elements due to alteration, especially the LREE, it has not been possible to model the evolution of the $\boldsymbol{U M}$. However, a qualitative approach shows that fractionation of olivine and othopyroxene could cause $\mathrm{SiO}_{2}, \mathrm{Al}_{2} \mathrm{O}_{3}, \mathrm{FeOt}, \mathrm{CaO}$ and $\mathrm{TiO}_{2}$ enrichment and $\mathrm{MgO}$, Ni and $\mathrm{Cr}$ impoverishment (Figures 2, $3,5)$.
Taking $m g \#$ as differentiation index (Figure 6), the tholeiites $(\boldsymbol{B} \boldsymbol{A} \boldsymbol{S}, \boldsymbol{G B})$ are roughly similar to the $\boldsymbol{U M}$. The main difference is their strong $\mathrm{CaO}$-impoverishment, and, at a lesser extent, in $\mathrm{Al}_{2} \mathrm{O}_{3}$ for tholeiites, which indicate plagioclase and clinopyroxene fractionation. $\mathrm{Ni}, \mathrm{Cr}, \mathrm{Sc}$ and $\mathrm{Sr}$ have a compatible behavior, which can also be explained by clinopyroxene, plagioclase and, possibly, olivine fractionation. The MgO$\mathbf{C a O}-\mathrm{Al}_{2} \mathrm{O}_{3}$ triangle (Figure 2b) corroborates the assumed control exercised by $\mathrm{MgO}$-rich minerals in the case of $\boldsymbol{U} \boldsymbol{M}$ and by $\mathrm{CaO}$-rich phases for tholeiites. Some quantitative modeling for $\boldsymbol{B} \boldsymbol{A S}$ and $\boldsymbol{G B}$ of the Identidade belt was made by Souza (1994) and Souza \& Dall'Agnol (1995c). They used the Xlfrac program (Stormer Jr. \& Nicholls 1978) for major and minor 

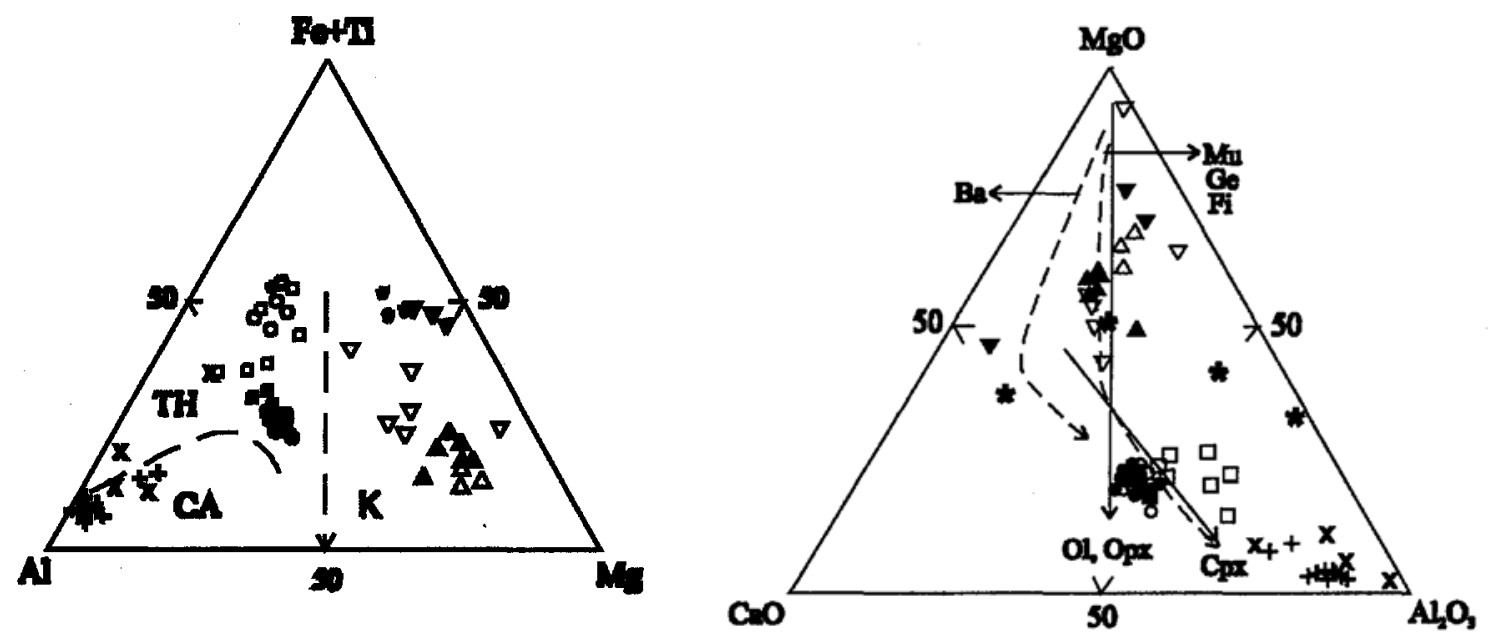

(c)

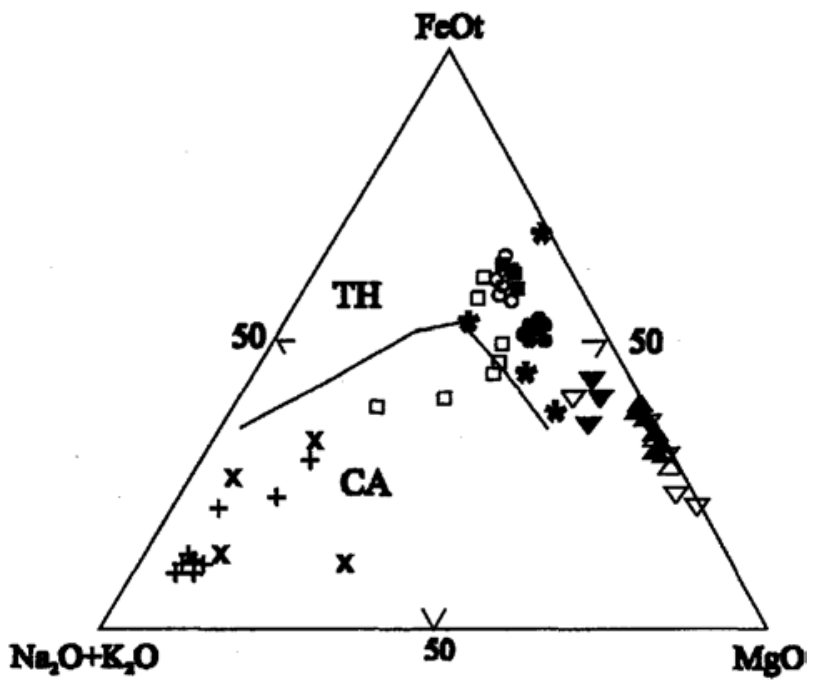

Figure 2 - Geochemical characteristics of the metavolcanic rocks of greenstone belts from southern Pará State. (a) Cationic proportions of (Fet+Ti)-Al-Mg (Jensen 1976): $\mathrm{CA}=$ calc-alkaline, $\mathrm{TH}=$ tholeitie, $\mathrm{K}=$ komatiite. (b) $\mathrm{MgO}-\mathrm{CaO}-\mathrm{Al}_{2} \mathrm{O} 3$ with the evolution trends for mafic-ultramafic rocks from Barberton (Ba), Munro (Mu), Geluk (Ge) and Finland (Fi) (Auvray et al. 1982, Schulz 1982); the continuous curves mark the control of the fractionation of olivine (Ol), orthopyroxene (Opx) and clinopyroxene (Cpx). (c) AFM (Kuno 1968, Irvine \& Baragar 1971); $\boldsymbol{C A}=$ calc-alkaline, $\boldsymbol{T H}=$ tholeiitic. Symbols for komatiites: $\triangle$ Identidade belt (Souza \& Dall'Agnol 1995c), A Seringa belt (Huhn et al. 1986), $\nabla$ Sapucaia belt (Oliveira 1987), $\nabla$ Lagoa Seca belt (Nascimento \& Biagini 1988); tholeiites: $\mathbf{\Delta}$ basalts of the Identidade belt (Souza \& Dall'Agnol 1995c), $\square$ gabbros of the Identidade belt (Souza \& Dall'Agnol 1995c), O basalts of the Babaçu belt (Gama Jr. et al. 1982), $\square$ basalts of the Babaçu belt (Huhn I992),

basalts of the Lagoa Seca belt (Nascimento \& Biagini 1988); calc-alkalines: + Identidade belt (Souza 1994), x Sapucaia belt (Oliveira 1987).

Figura 2 - Características geoquímicas de rochas metavulcânicas de greenstone belts do sul do Pará. (a) Diagrama catiônico (Fet+Ti)-Al-Mg (Jensen 1976): CA $=$ cálcico-alcalino, $\mathbf{T H}=$ toleíto, $\mathbf{K}=$ komatiito. (b) $\mathbf{M g O}-\mathbf{C a O}-\mathrm{Al}_{2} \mathrm{O}_{3} \mathrm{com}$ as tendências seguidas por rochas máficas - ultramáficas de Barberton (Ba), Munro (Mu), Geluk (Ge) e Finlândia (Fi) (Auvray et al. 1982, Schulz 1982); as curvas contínuas indicam o controle exercido pelo fracionamento de olivina (Ol), ortopiroxênio (Opx) e clinopiroxênio (Cpx). (c) AFM (Kuno 1968, Irvine \& Baragar 1971); CA = cálcico-alcalino, TH = toleítico. Símbolos usados para komatiitos: $\triangle$ Faixa Identidade (Souza \& Dall'Agnol 1995c), $\Delta$ Faixa Seringa (Huhn et al. 1986), $\nabla$ Faixa Sapucaia (Oliveira 1987), $\nabla$ Faixa Lagoa Seca (Nascimento \& Biagini 1988); tolé́tos: - basaltos da Faixa Identidade (Souza \& Dall'Agnol 1995c), a gabros da Faixa Identidade (Souza \& Dall'Agnol 1995c), 0 basaltos da Faixa Babaçu (Gama Jr. et al. 1982), ] basaltos da Faixa Babaçu (Huhn 1992), * basaltos da Faixa Lagoa Seca (Nascimento \& Biagini 1988); cálcico-alcalinos: + Faixa Identidade (Souza 1994), x Faixa Sapucaia (Oliveira 1987).

elements, and assumed the equilibrium crystallization for trace elements (Shaw 1970). They considered a initial liquid with mg\#=0.59, $\mathrm{Al}_{2} \mathrm{O}_{3}=15.72$ wt $\%, \mathrm{Fe}_{2} \mathrm{O}_{3} \mathrm{t}=11.9$ wt $\%$, $\mathrm{CaO}=12.81 \mathrm{wt} \%, \mathrm{TiO} 2=0.69 \mathrm{wt} \%$ and $\Sigma \mathrm{REE}=28.98 \mathrm{ppm}$, and a differentiated liquid with $\mathrm{mg} \#=0.52, \mathrm{Al}_{2} \mathrm{O}_{3}=16.12 \mathrm{wt}$ $\% \mathrm{Fe}_{2} \mathrm{O}_{3} \mathrm{t}=13.4$ wt $\%, \mathrm{CaO}=11.09$ wt $\%, \mathrm{TiO}_{2}=0.85$ wt $\%$ and $\mathrm{ZREE}=36.29 \mathrm{ppm}$. Their models indicated a degree of crystallization in between $20 \%$ and $55 \%$, the fractionation mainly controlled by clinopyroxene and plagioclase (labradorite), with lesser amounts of magnetite and olivine.

The $\boldsymbol{D} \boldsymbol{A C}$ are slightly peraluminous (normative corindon $>2 \%$ ). Their contents in major, minor and trace elements (including the REE) are somewhat similar to those ones of Cenozoic Tonalites - Trondhjemites - Dacites (TTDs) associations described by Drummond \& Defant (1990), as well as to felsic volcanics from Archean greenstone belts (FI type, 

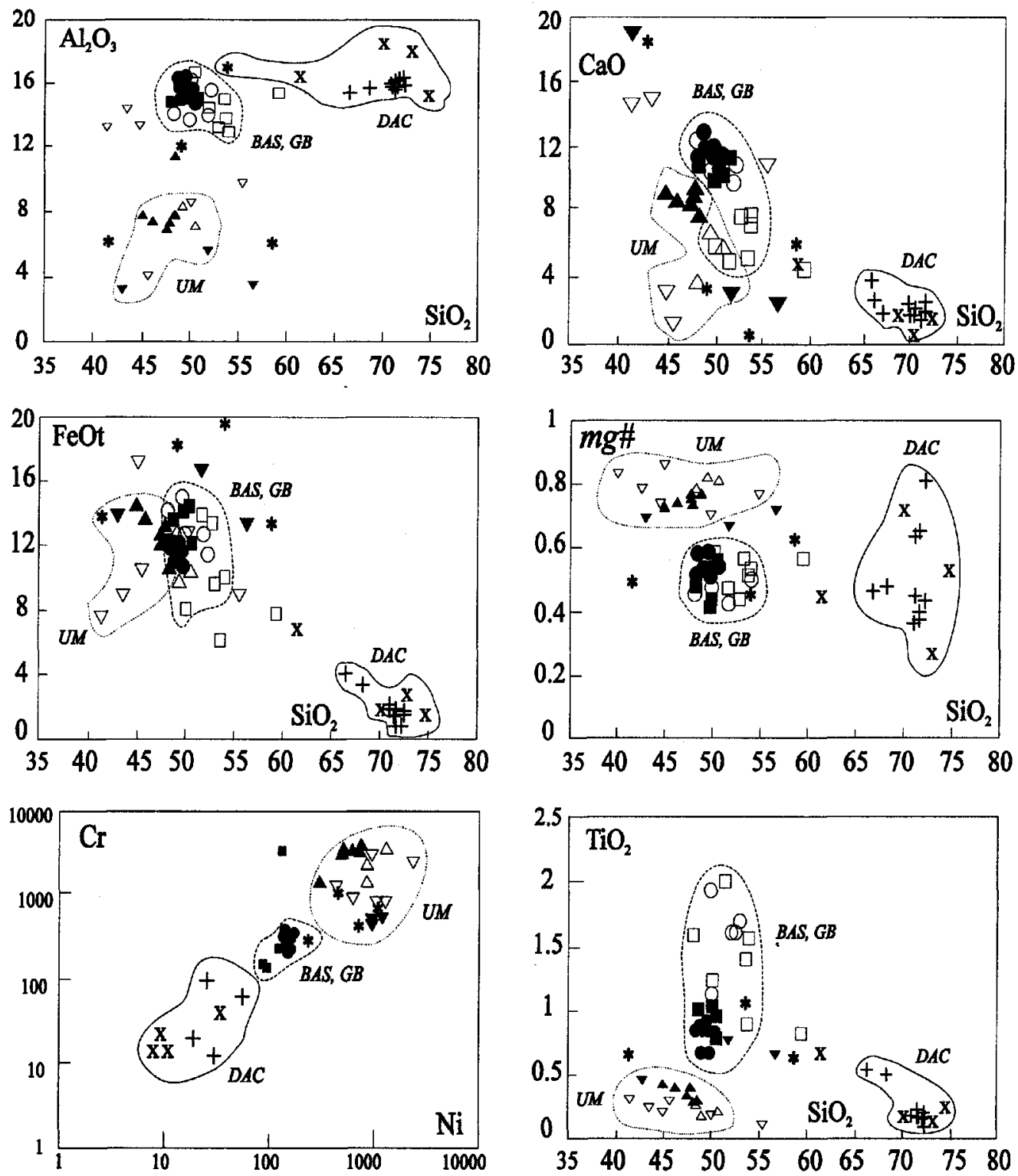

Figure 3 - Variation diagrams with the fields for komatiite (UM), tholeiite (BAS, GB) and calc-alkaline rocks (DAC). Symbols as in Figure 2.

Figura 3 - Diagramas de variação com os campos correspondentes às rochas komatíticas $(\boldsymbol{U M})$, toleíticas $(\boldsymbol{B} \boldsymbol{A} \boldsymbol{S}, \boldsymbol{G B})$ e cálcico-alcalinas $(\boldsymbol{D} \boldsymbol{A C})$. Os símbolos são os mesmos da Figura 2.

Condie 1981). Using $\mathrm{SiO}_{2}$ as differentiation index (Figure 7), the $\boldsymbol{D} \boldsymbol{A C}$ show an increase in $\mathrm{AhOs}$ and $\mathrm{Na}_{2} \mathrm{O}$ and decrease in $\mathrm{FeOt}, \mathrm{MgO}, \mathrm{CaO}, \mathrm{K}_{2} \mathrm{O}$ and $\mathrm{TiO}_{2}$. These patterns can be explained by the fractionation of hornblende, plagioclase, sphene, biotite and magnetite. This hypothesis is in accordance with the petrographic features of these rocks. This is also corroborated by the compatible behavior of $\mathrm{Eu}, \mathrm{Sr}, \mathrm{Zr}, \mathrm{Th}, \mathrm{U}$, $\mathrm{V}, \mathrm{Cr}$, Sc, suggesting the additional fractionation of zircon. In the same manner as for tholeiites, quantitative modeling for $\boldsymbol{D} \boldsymbol{A C}$ of the Identidade belt was made by Souza (1994) and Souza and Dall'Agnol (in press). They consider the initial and differentiated liquids with the following compositions: $\mathrm{SiO}_{2}=68.27 / 72.24$ wt $\% ; \quad \mathrm{Al}_{2} \mathrm{O}_{3}=15.63 / 15.6$ wt $\%$; $\mathrm{Fe}_{2} \mathrm{O}_{3} \mathrm{t}=3.7 / 1.56$ wt $\% ; \mathrm{MgO}=1.69 / 0.71$ wt $\% ; \mathrm{CaO}=3.99 /$ 1.69 wt $\% ; \mathrm{Na}_{2} \mathrm{O}=3.89 / 5.68$ wt $\% ; \mathrm{K}_{2} \mathrm{O}=0.49 / 0.19$ wt $\%$, $\mathrm{TiO}_{2}=0.49 / 0.19$ wt $\%, \quad \Sigma \mathrm{REE}=151.58 / 36.23 \quad \mathrm{ppm}$, $(\mathrm{La} / \mathrm{Sm}) \mathrm{N}=4.5 / 2.6$ and $(\mathrm{Gd} / \mathrm{Yb}) \mathrm{N}=4.3 / 2.8$. They obtained two possible cumulates, one of them with plagioclase, clinopyroxene, hornblende, magnetite and sphene, and a degree of fractional crystallization of $17 \%$, and the other one with plagioclase, quartz, biotite, hornblende, K-feldspar, magnetite and sphene, and $62 \%$ of fractional crystallization.

\section{MAGMA GENESIS AND TECTONIC SETTING}

Magma genesis concerning the $\boldsymbol{U M}$ and $\boldsymbol{B} \boldsymbol{A} \boldsymbol{S}+\boldsymbol{G} \boldsymbol{B}$ of the Identidade belt were discussed by Souza (1994) and Souza \& Dall'Agnol (1995c) based on the behavior of some trace elements and the position of the less evolved samples in a normalized $(\mathrm{La} / \mathrm{Yb}) \mathrm{N} v s$. $\mathrm{Yb}_{\mathrm{N}}$ plot (Jahn et al. 1981, Martin 1986). In the case of komatiites and tholeiites, those authors considered the source as a slightly depleted garnet (1-5\%) Iherzolite, melted from $10 \%$ to $25 \%$. Concerning the $\boldsymbol{U M}$ it would be possible to generate the komatiitic liquid firstly by $35 \%$ of partial melting of a Iherzolite having up to $5 \%$ garnet 


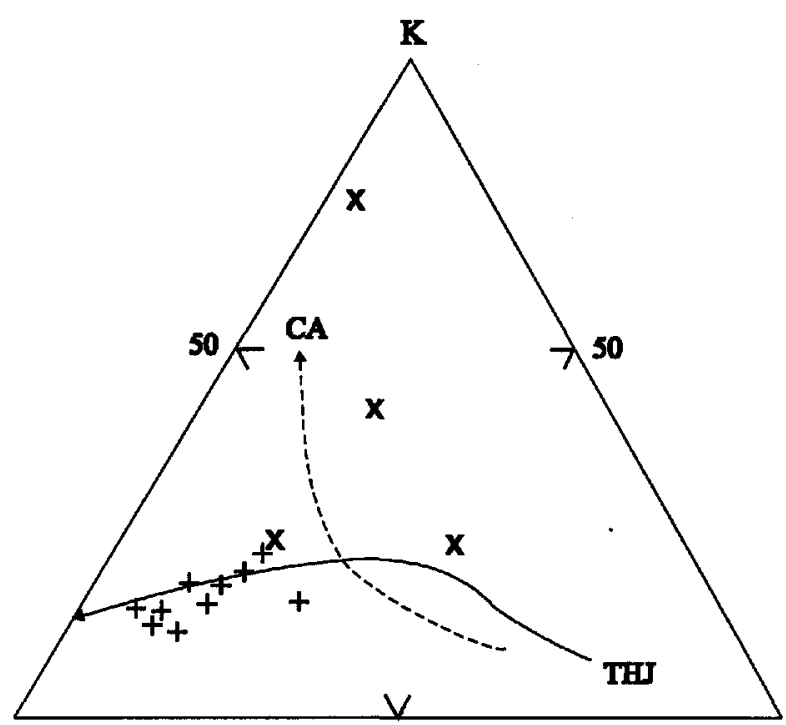

$\mathrm{Na}$

50

$\mathrm{Ca}$

Figure 4 - K-Na-Ca plot offelsic metavolcanic rocks from Identidade and Sapucaia greenstone belts. Trends for calc-alkaline (CA) and trondhjemitic (THJ) series as defined by Nockolds \& Allen (1953) and Barker \& Arth (1976) are also shown. Other symbols as in Figure 2. Figura 4 - Diagrama catiônico K-Na-Ca para as rochas metavulcânicas félsicas dos greenstone belts Identidade e Sapucaia. Também são mostradas as tendências evolutivas de séries cálcico-alcalinas (CA) e trondhjemíticas (THJ) definidas por Nockolds \& Allen (1953) e Barker \& Arth (1976). Outros símbolos são explicados na Figura 2. followed by $60 \%$ to $65 \%$ of fractional crystallization of olivine. With regard to $B A S$ and $\boldsymbol{G B}$ of the Identidade belt, Souza \& Dali'Agnol (1995c) calculated a harzburgitic residue, with less than $5 \%$ of garnet, which is consistent with the contents of $\mathrm{Co}, \mathrm{Ni}, \mathrm{Rb}, \mathrm{Y}$ and $\mathrm{Sr}$ of the tholeiitic liquids.

The $\boldsymbol{U} \boldsymbol{M}$ of Identidade and Seringa have geochemical characteristics similar to the so-called Al-undepleted komatiites (Nesbitt et al. 1979, Jahn et al. 1982): chondritic $\mathrm{CaO} / \mathrm{Al}_{2} \mathrm{O}_{3}(=0.8)$ and $\mathrm{Al}_{2} \mathrm{O}_{3} / \mathrm{TiO}_{2}(\cong 20)$ values and almost flat or slight fractionated $\mathrm{HREE}((\mathrm{Gd} / \mathrm{Yb}) \mathrm{N}=0.9-1.6)$. This kind of komatiites are typical of the late Archaean from Canada and Australia, and considered as originated by high degree $(50 \%)$ of partial melting of peridotitic mantle in the pressure range 5 to $7 \mathrm{GPa}(150$ to $250 \mathrm{~km}$ ) (Ohtani 1989, Herzberg 1995), their source containing no or few pyropic or majoritic garnet (Jahn et al. 1982, Ohtani 1990, Herzberg 1995).

The tectonic setting of Archaean komatiites is difficult to understand due mainly to varying degrees of alteration of these rocks. It resulted in several hypotheses, as for example ocean floor, island arc, meteoritic impact, primitive crust, continental crust submitted to extension, and subduction of ultramafic crust (Brooks \& Hart 1974, Allègre 1982, Nisbet 1982). However, reinterpretations of the classical greenstone belts from South Africa indicate that komatiites could be relicts of oceanic plateaus: ophiolites associated to hot spots at divergent plate margins (Helmstaedt et al. 1986, Storey et al. 1991, Kusky \& Kidd 1992, McDonough \& Ireland 1993). On the other hand, Archaean komatiites geochemistry, is also accounted by melting in the transition zone of plumes that were $200-300^{\circ} \mathrm{C}$ hotter than the ambient mantle at that time (Herzberg 1992, 1995).
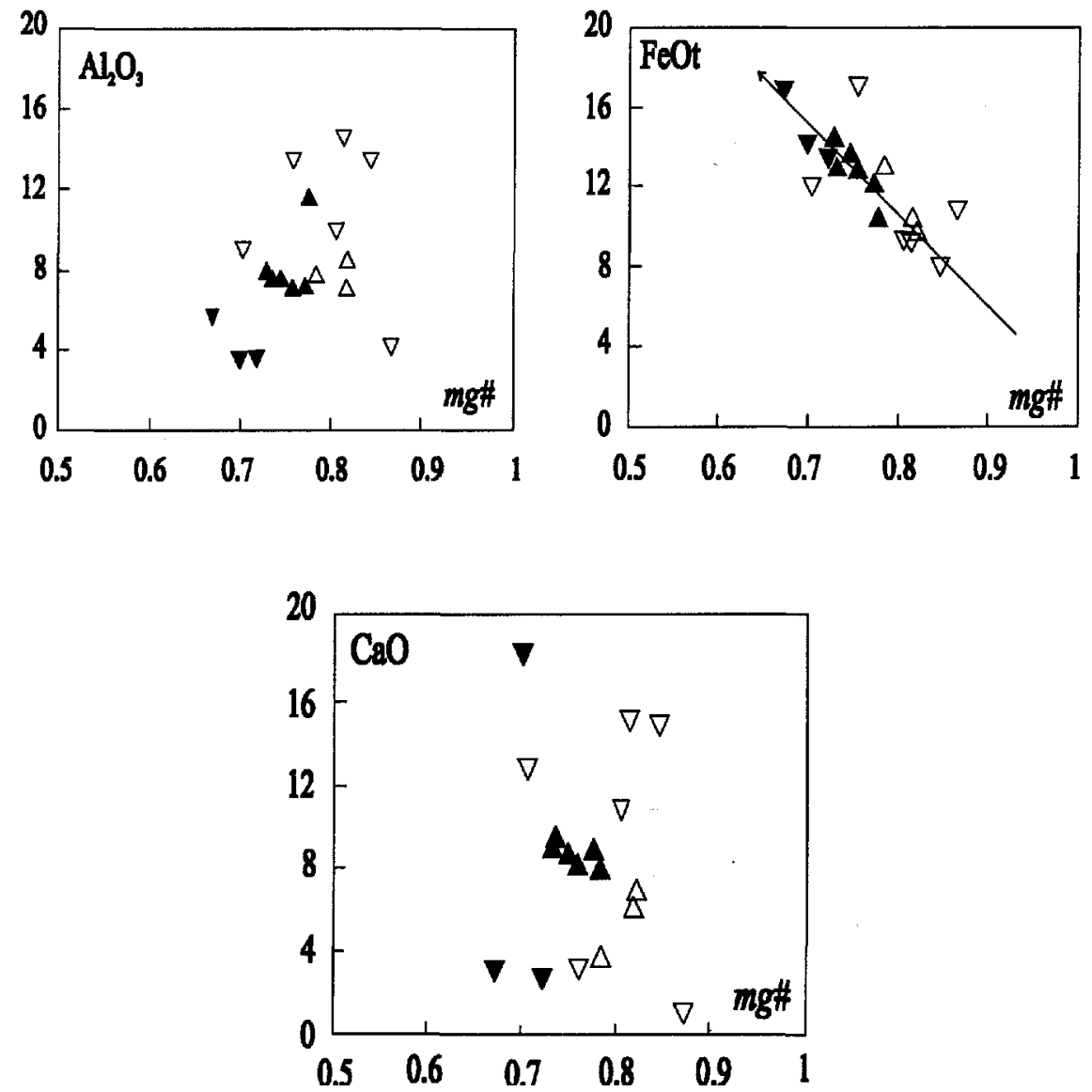

Figure 5 - Variation diagrams for komatiites. Symbols as in Figure 2.

Figura 5 - Diagramas de variação para os komatiitos. Os símbolos são os mesmos da Figura 2. 

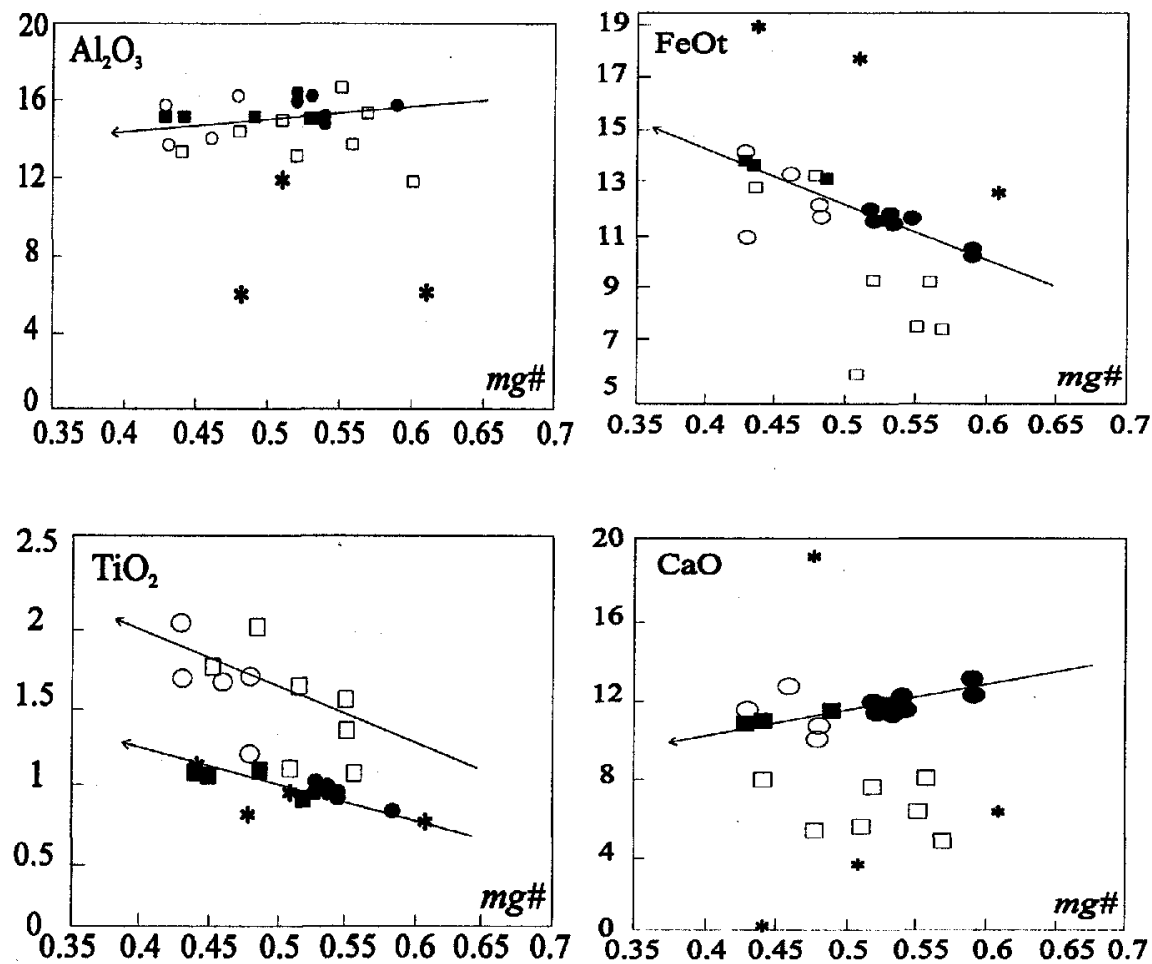

Figure 6 - Variation diagrams with respect to magnesium number (mg\#)for tholeiites. Symbols as in Figure 2. Figura 6 - Diagramas de variação com respeito ao número de magnésio (mg\#) para os toleítos. Os símbolos são os mesmos da Figura 2.
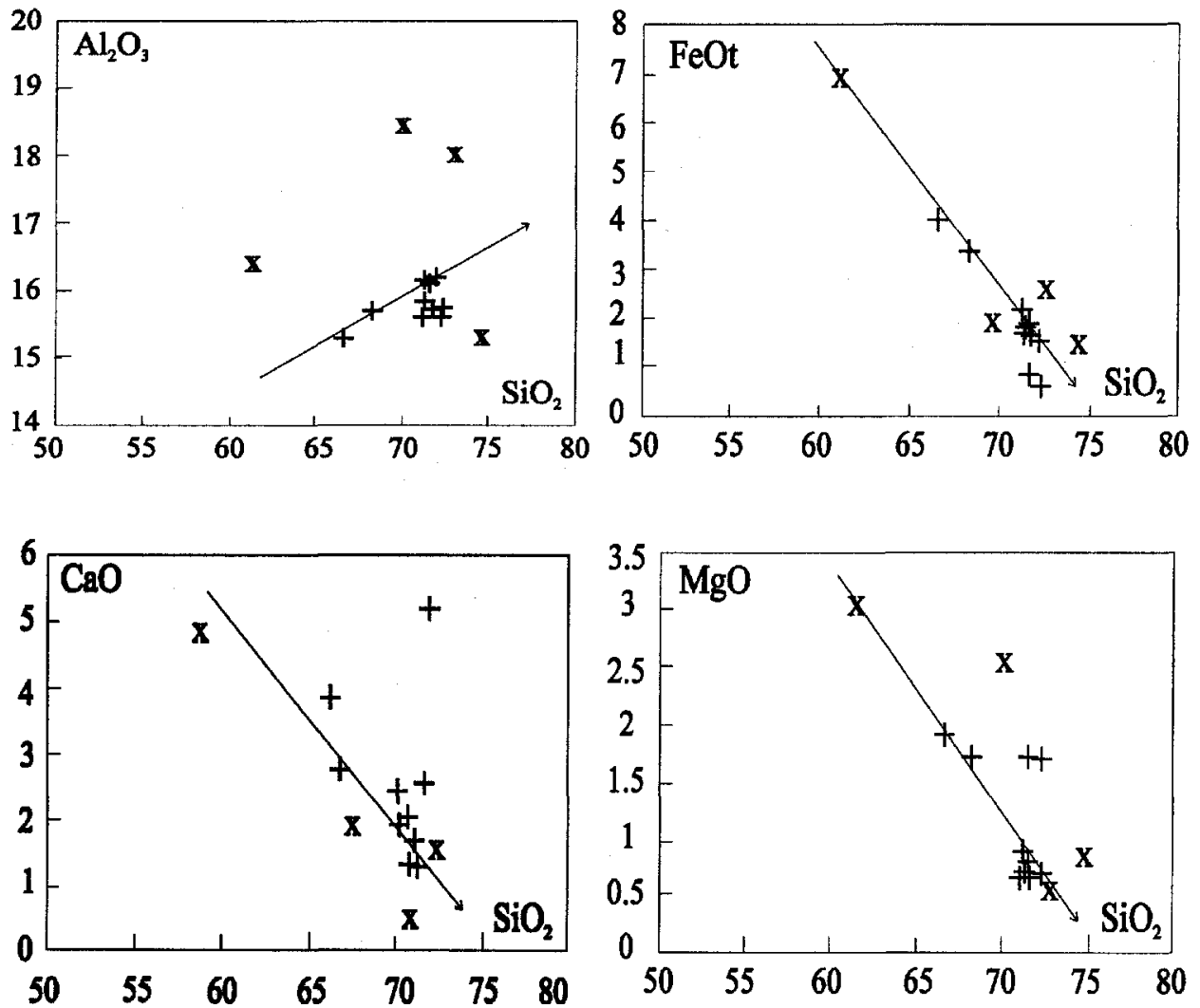

Figure 7 - Marker diagrams for sodic calc-alkaline rocks. Symbols as in Figure 2.

Figura 7 - Diagramas de Marker para as rochas cálcico-alcalinas. Os símbolos são os mesmos da Figura 2. 
(a)

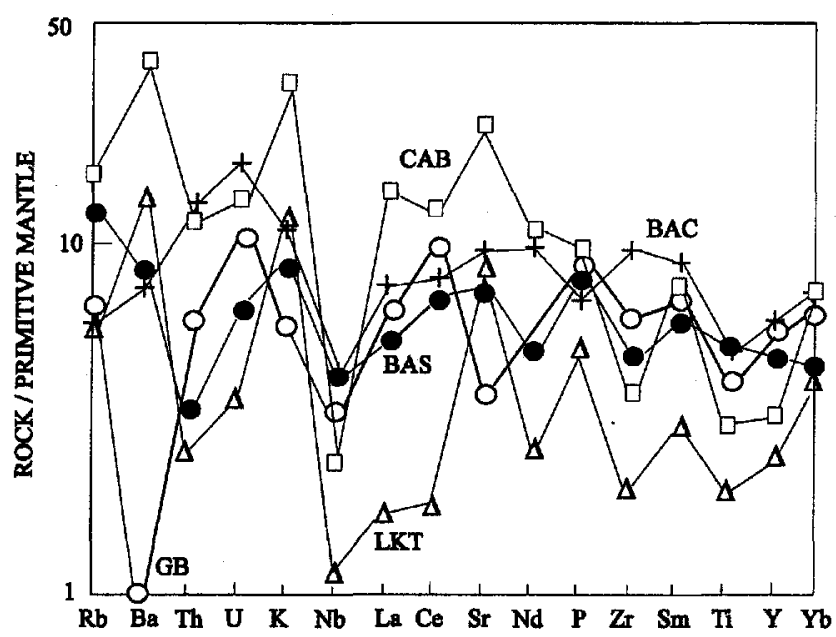

Figure 8 -Spider grams for the tholeiites $(\bullet$ basalts, average of 7 samples; 0 gabbros, average of 4 samples) of the Identidade greenstone belt. For comparisons there are also the patterns for calc-alkaline basalts (CAB, $\square$ Wilson 1989), back-arc basalts (BAC, +, Holm 1985) and low-K tholeiites (LKT, $\Delta$ Wilson 1989). All the elements were normalized using primitive mantle values from Wood et al. (1979). Figura 8 - Diagramas multi-elementares de toleítos (• basaltos, média de 7 amostras; $\mathrm{O}$ gabros, média de 4 amostras) do greenstone belt Identidade. Para comparação, também foram plotados os padrões de basaltos cálcico-alcalinos (CAB, $\square$ Wilson 1989), basaltos de bacia marginal (BAC, + , Holm 1985) e toleítos de baixo potássio (LKT, $\Delta$ Wilson 1989). Todos os elementos foram normalizados usando-se os valores do manto primitivo segundo Wood et al. (1979).

Several diagrams were proposed in order to discriminate the tectonic setting of tholeiites. Diagrams considering $\mathrm{Fe}$ (FeOt-MgO- $\mathrm{Al}_{2} \mathrm{O}_{3}$; Pearce et al 1977) or $\mathrm{Mn}\left(\mathrm{TiO}_{2}-10 \mathrm{MnO}-\right.$ $10 \mathrm{P}_{2} \mathrm{O}_{5}$; Mullen 1983) were discarded due the evidences of iron oxidation and the low concentrations of $\mathrm{MnO}$. Others diagrams furnished ambiguous answers, as the F1-F2 (Pearce 1979) and $100 \mathrm{TiO}_{2}-\mathrm{Zr}-3 \mathrm{Y}$ (Pearce \& Cann 1973) and $\mathrm{Zr} / \mathrm{Y}-\mathrm{Zr}$ (Pearce \& Norry 1976), where the tholeiites plotted either as calc-alkaline (island arc or active continental margin) or in the low-K tholeiite or MORE fields. Spidergrams of $\boldsymbol{B} \boldsymbol{A S}$ and $\boldsymbol{G B}$ of the Identidade belt suggest their affinity with low-K tholeiites; however they are also similar to back-arc basalts if we consider the probable less mobile element $\mathrm{P}$ to $\mathrm{Yb}$ (Figure 8).

The calc-alkaline character, the low initial $\mathrm{Sr}$ ratios $(0,70219+/-0.00029,1 \sigma$; Souza et al. 1992a) and the REE patterns of $\boldsymbol{D} \boldsymbol{A C}$ indicate that they have some type of source and petrologic evolution as interpreted for Archaean TTGs (Tonalites - Trondhjemites -Granodiorites) (Barker \& Arth 1976, Martin 1986, 1994) and TTDs (Drummond \& Defant 1990, Martin 1986, 1994). In these cases, the source is considered as being the oceanic crust transformed into garnet amphibolite or eclogite in a subduction zone setting (Drummond \& Defant 1990, Martin 1986,1994). Souza \& Dall'Agnol (in press) considered the average composition of Identidade belt tholeiites enriched in incompatible elements $\left(\mathrm{La}_{\mathrm{N}}=30\right.$ and $\left.(\mathrm{La} / \mathrm{Yb})_{\mathrm{N}}=3.4\right)$ as that oceanic crust. In such a way, they concluded that $10 \%$ to $15 \%$ of partial melting of this source could generate the dacitic liquid, leaving a residue

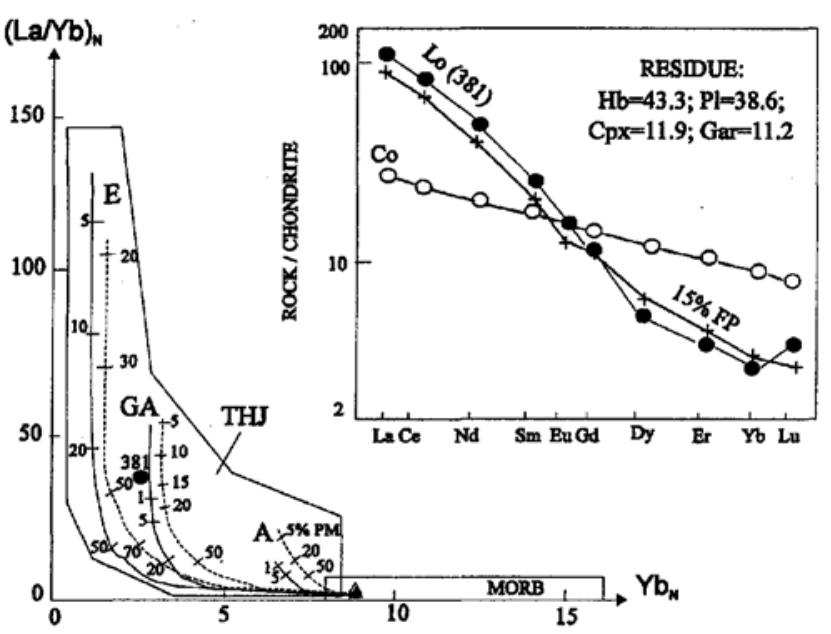

Figure 9 - (a) Plot of the less evolved metadacitic sample from Identidade greenstone belt $(\bullet$, Lo $=381)$ in a normalized $(\mathrm{La} / \mathrm{Yb})$ vs. Yb diagram. The continuous and spaced curves represent respectively the evolution by partial melting (PM) of depleted $(\boldsymbol{\Delta})$ and enriched $(\Delta)$ tholeiitic sources transformed into amphibolite $(\boldsymbol{A})$, garnet amphibolite $(\boldsymbol{G A})$ and eclogite $(\boldsymbol{E})$. (b) Modeling by partial melting of enriched garnet amphibolite ( $\mathrm{O}, \boldsymbol{C o})$ generates the dacitic liquid (+) and leaves a residue composed by hornblende (Hb), plagioclase $(\boldsymbol{P l})$, clinopyroxene (Cpx) and garnet (Gar) (Souza \& Dall'Agnol in press).

Figura 9 - (a) Plote da amostra menos evoluída do metadacito do greenstone belt Identidade $\left(\bullet, L_{0}=387\right)$ no diagrama normalizado $(L a / Y b)$ vs. Yb. As curvas contínua e tracejada indicam as respectivas evoluções por fusão parcial de toleíto empobrecido $(\boldsymbol{\Delta})$ e enriquecido $(\Delta)$ transformado em anfibolito (A), granada anfibolito (GA) e eclogito (E), (b) Modelamento de fusão parcial de granada anfibolito enriquecido em elementos incompatíveis $(\mathrm{O}, \boldsymbol{C o})$ gera um líquido dacítico $(+)$ e deixa um resíduo composto de hornblenda $(\mathrm{Hb})$, plagioclásio (PI), clinopiroxênio $(\mathbf{C p x})$ e granada (Gar) (Souza \& Dall'Agnol no prelo).

composed by hornblende (43\%), plagioclase (andesine, 34\%), clinopyroxene (12\%) and garnet (11\%) (Figure 9).

The petrological characteristics of DAC is the fractionation of hydrated minerals (hornblende, biotite) and high $\mathrm{fO}_{2}$ phases (magnetite, sphene). This has been reported in modern subduction zone environments (Martin 1986). In the case of DAC of the Identidade belt, $\mathrm{Rb}$ and $\mathrm{Y}+\mathrm{Nb}$ diagrams and spidergrams (Pearce et al. 1984) show similarities with granitoids and volcanics from island arcs (high $\mathrm{Rb}$ and $\mathrm{Ba}$ contents, and negative $\mathrm{Nb}$ and $\mathrm{Zr}$ anomalies), and differences with syncolisional and withinplate magmas. In this context, it is possible that the subducted oceanic crust contained terrigenous component and has been enriched in incompatible elements such as $\mathrm{U}, \mathrm{Th}, \mathrm{Rb}, \mathrm{Ba}, \mathrm{Cs}$, and LREE. The terrigenous component could also be a source for refractory minerals that accommodate the HREE (ex. zircon) (Maaløe \& Peterson 1981, Westercamp 1988, Sorensen \& Grosmam 1989, Stern et al. 1991). The metagraywackes found in the greenstone belts could be this terrigenous component, as they contain detrital plagioclase, quartz, biotite, apatite, zircon, sphene and allanite (Dall'Agnol et al. 1985). Preliminary modeling of major and minor elements by mixing metagraywackes of the Lagoa Seca belt (chemical analyses from Gama Jr. et al. 1982) with tholeiites of the Identidade belt corroborates the contamina- 


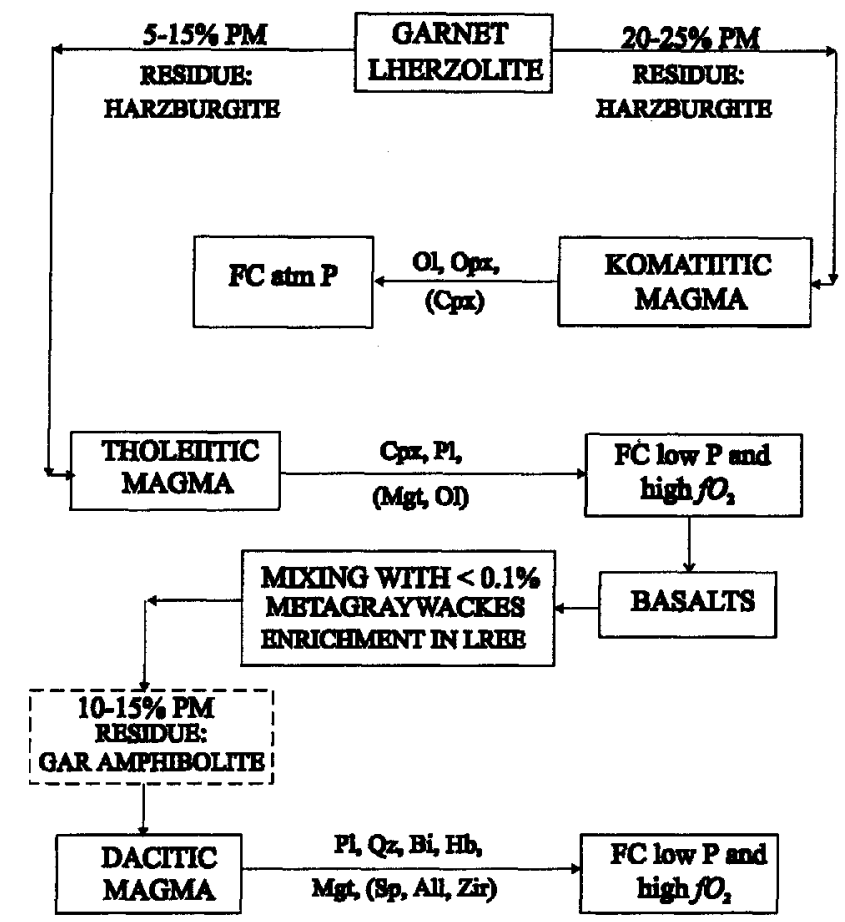

Figure 10 - Integrated model of evolution of the volcanism of greenstone belts from the Rio Maria region, including the stages of partial melting (PM) and fractional crystallization (FC). Symbols: $\boldsymbol{O l}=$ olivine, $\boldsymbol{O p x}=$ orthopyroxene, $\boldsymbol{C p x}=$ clinopyroxene, $\boldsymbol{P l}=$ plagioclase, $\boldsymbol{Q} \boldsymbol{z}=$ quartz, $\boldsymbol{B \boldsymbol { i }}=$ biotite, $\boldsymbol{H b}$ - hornblende, $\boldsymbol{M g t}=$ magnetite, $\boldsymbol{S p}=$ sphene, $\boldsymbol{A l l}=$ allanite, Zir - zircon, Gar = garnet; atm $P=$ atmospheric pressure.

Figura 10 - Modelo integrado de evolução do vulcanismo de greenstone belts da região de Rio Maria, englobando os estágios de fusão parcial (PM) e cristalização fracionada $(\mathbf{F C})$. Símbolos: $\mathbf{O l}=$ olivina, $\mathbf{O p x}=$ ortopiroxênio, $\mathbf{C p x}=$ clinopiroxênio, $\mathbf{P I}=$ plagioclásio, $\mathbf{Q z}=$ quartzo, $\mathbf{B i}=$ biotita, $\mathbf{H b}=$ hornblenda, $\mathbf{M g t}=$ magnetita, $\mathbf{S p}=$ titanita, $\mathbf{A l l}=$ alanita, $\mathbf{Z i r}=$ zircão, Gar = granada; atm $\mathrm{P}=$ pressão atmosférica.

tion hypothesis. Moreover, the presence of inherited zircons in metadacites of the Lagoa Seca belt (Pimentel \& Machado 1994 ) is coherent with this assumption.

DISCUSSIONS AND CONCLUSIONS Figure 10 integrates the data discussed above. It shows the stages of magma generation and mechanism of petrogenetic evolution for the mafic - ultramafic and felsic meta volcanic rocks of the Archaean greenstone belts of the Rio Maria region. As main conclusion it is stated the existence of three distinct magmatic series, the older one being komatiites $(\boldsymbol{U M})$ and low-K tholeiites $(\boldsymbol{B} \boldsymbol{A} \boldsymbol{S}$ and $\boldsymbol{G B})$ and the younger ones being sodic (trondhjemitic) calc-alkaline $(\boldsymbol{D} \boldsymbol{A C})$. A common feature is that they evolved mainly by low pressure fractional crystallization.

The low degree of partial melting (20-25\%) of the upper mantle to generate komatiites is not consistent with experi- mental results of Green et al. (1975) and Arndt (1976). However, it agrees well with theoretical discussions made by Rajamani et al. (1985). Relative low melting degree could be explained by melting of Iherzolite at greater depths (Miller et al. 1991), batching melting (Arndt 1991) or successive low percentages of melting during adiabatic decompression (Green 1975, Wilson 1989).

Geochemical patterns and source modeling suggest that the greenstone belts started their evolution as marginal basins or some few oceanic plateaus (komatiitic - tholeiitic volcanism). The dacitic calc-alkaline volcanism post-dates the mafic ultramafic one and would be contemporaneous with crustal shortening of the island arc and closure of that marginal basin (Souza 1994). This temporal succession is consistent with the litostratigraphic units of the greenstone belts and also with the sources considered in partial melting modeling. The closure of the marginal basin favored the progressive involvement of crustal components in the last stages of evolution of the greenstone belts, being more expressive at the time of generation of the dacitic volcanism $(2.97-2.90 \mathrm{Ga})$ and subsequent granitoid plutonism $(2.87 \mathrm{Ga})$. At that time there would have been exposition of island arcs and of the Arco Verde Tonalite (Tav), propitiating their denudation and giving rise to deposition of immature sediments (gray wackes and siltstones).

However, the existence (or not) of an older continental crust before the greenstone belt emplacement is suggested by inherited zircons from the Musa anorogenic granite massif (Machado et al. 1991), quartzites from the Rio Fresco Group (Macambira \& Lancelot 1991, Macambira 1992) and metadacites from the Lagoa Seca belt (Pimentel \& Machado 1994) which give ages older than $3.0 \mathrm{Ga}$. They are greater than that obtained for the $\operatorname{Tav}$ (U-Pb zircon, $2.96 \mathrm{Ga}$, Macambira 1992). Hence, the Tav could not be the oldest continental basement of the greenstone belts, but they were already exposed at the time of deposition of the metagray wackes, which contain detrital zircons of $c a$. $2.97 \mathrm{Ga}$ (Macambira 1992). The searching for continental evidences from komatiites and thpleiites needs $\mathrm{Sr}$ and $\mathrm{Nd}$ isotopic data, but the high $\mu$. $\left({ }^{238} \mathrm{U} /{ }^{204} \mathrm{~Pb}=9.66\right)$ (Souza 1994), Rb and $\mathrm{U}$ in some $\boldsymbol{B} \boldsymbol{A} \boldsymbol{S}$, as well as high $\mathrm{Th}, \mathrm{U}$ and $\mathrm{Nb}$ in some $\boldsymbol{G B}$, suggest that some kind of continental crust existed prior to the mafic -ultramafic magmatism.

The calc-alkaline volcanism $(2.97-2.90 \mathrm{Ga})$ marks a transition from one stage where the magmatism originated directly from the mantle (partial melting of Iherzolite generating the komatiites and tholeiites) to a stage of crustal recycling (partial melting of tholeiite transformed into garnet amphibolite). This stage reached the maximum development during the voluminous granitoid plutonism ( $c a$. 2,87 Ga) when all the components of the granite -greenstone terrane reached their tectonic stabilization, and acted as cratonic blocks with regards to the geodynamic events responsible for the implantation of the Neoarchaean units of the northern portion of the Carajás Mineral Province (Souza et al. 1996).

Acknowledgments The authors are grateful to $\mathrm{CNPq}$ and CAPES for scholarships (ZSS, CGO) and FINEP/PADCT (research projects 4/3/87/0911/00 and 65/92/0025/00, RD) for financial support, CRPG/Nancy and CG/UFPA for analytical data, CVRD-Docegeo/AM for unpublished results, and two anonymous reviewers. Critical comments and English improvements of $\mathrm{H}$. Martin were very helpful. 


\section{REFERENCES}

Allegre, C.J. 1982. Genesis of Archean komatiites in a wet ultramafic subducted plate. In: ARNDT, N.T. \& NISBET, E.G. eds. Komatiites. London, George Allen \& Unwin, p. 495-500.

Althoff, F.J.; Barbey, P.; Boullier, A.M.; Dall'Agnol, R . 1995. Composição e estrutura de granitóides arqueanos da região de Marajoara. Boi. Museu Paraense Emílio Goeldi, Ciências da Terra, 7:5-26.

Arndt, N.T. 1976. Melting relations of ultramafic lavas (komatiites) at one atmosphere and high pressure. Carnegie Inst. .Wash. Yearbook, 75:555-561

Arndt, N.T. 1991. High $\mathrm{Ni}$ in Archean tholeiites. Tectonophysics, 187:411-419.

Arndt, N.T. \& Nisbet, E.G. 1982. What is a komatiite. In: ARNDT, N.T. \&

NISBET, E.G. eds. Komatiites. London, George Allen \& Unwin, p.

19-27.

Arndt, N.T.; Naldrett, A.J.; Pyke, D.R. 1977. Komatiitic and iron-rich tholeiitic lavas of Munro Towship, northeast Ontario. /. Petrol., 18:319-369.

Auvray, B.; Blais, S.; Jahon B.M.; Piquet, P. 1982. Komatiites and the komatiitic series of Finnish greenstone belts. In: Arndt, N.T. \& Nisbet, E.G. eds. Komatiites. London, George Allen \& Unwin, p. 131-146.

Barker, F. \& Arth, J.G. 1976. Generation of trondhjemitic -tonalitic liquids and Archean bimodal trondhjemite - basalt suites. Geology, 4:596-600.

Brewer, T.S. \& Atkin, B.P. 1989. Elemental mobilities produced by low-grade metamorphic events. A case study from the Proterozoic supracrustals of Southern Norway. Precamb. Res., 45:143-158.

Brooks, C. \& Hart, S.R. 1974. On the significance of komatiite. Geology, 2:107-110

Condie, K.C. 1981. Archean greenstone belts. Amsterdam, Elsevier. 434p.

Cordeiro, A.A.C. 1982. Geologia preliminar da região de Andorinhas. In: SIMP. GEOL. AMAZ., 1. Belém, 1982. Atas...Belém, SBG, v. 1, p. $45-49$

Costa, J.B.S.; Araújo, O.J.B.; Santos, A.; Jorge João, X.S.; Macambira, M.J.B.; Lafon, J.M. 1995. A Província Mineral de Carajás: aspectos tectono-estruturais, estratigráficos e geocronológicos. Boi. Museu Paraense Emílio Goeldi, Ciências da Terra, 7:199-235.

Dall'Agnol, R.; Lafon, J.M.; Macambira, M.J.B. 1994. Proterozoic anorogenic magmatism in the Central Amazonian Province, Amazonian craton; geochronological, petrological and geochemical aspects. Mineral. Petrol., 50:113-138.

Dall'Agnol, R.; Schenato, C.A.; Cordeiro, A.A.C.; Scheller, T. 1985. Efeitos de contato do maciço granítico Jamon na seqüência Lagoa Seca (sudeste do Pará). In: SIMP. GEOL. AMAZ., 2. Belém, 1985. Anais...Belém, SBG, v. 2, p. 33-52.

Dall'Agnol, R.; Souza Z.S.; Althoff, F.J.; Macambira, M.J.B.; Leite, A.A.S 1996. Geology and geochemistry of the Archean Rio Maria granite greenstone terrain, Carajás Province, Amazonian craton. In: SYMP ARCHEAN TERRANES SOUTH AMERICAN PLATAFORM, Brasilia, 1996. Ext. /4fo/r...Brasflia, SBG, 29-30.

Dias, G.S.; Macambira, M.J.B.; Dall'Agnol, R.; Barros, C.E.M. 1996. Datação de zircões de sill de metagabro: comprovação da idade arqueana da Formação Águas Claras, Carajás, Pará. In: SIMP. GEOL. AMAZ., 5. Belém, 1996. Rés. Exp. e Guia Exc...Belém, SBG, p. 376-379.

DOCEGEO (Rio Doce Geologia e Mineração). 1988. Revisão litoestratigáfíca da Província Mineral de Carajás, Pará. In: CONGR. BRÁS. GEOL., 35. Belém, 1988. Anexo...Belém, SBG, v. "Província Mineral de Carajás -Litoestratigrafia e Principais Depósitos Minerais", p. 11-54.

Drummond, M.S. \& Defant, M.J. 1990. A model for trondhjemite - tonalite - dacite genesis and crustal growth via slab melting: Archean to modern comparisons. /. Geophys. Rés., 95:21503-21521.

Gama Jr., T.; Macambira, J.B.; Kotshoubey, B. 1982. Contribuição à litoestratigrafia da região da Serra das Andorinhas - sudeste do Pará. In: SIMP. GEOL. AMAZ., 1. Belém, 1982. Ato...Belém, SBG, v. 1 p. $111-127$

Green, D.H. 1975. Genesis of Archean peridotitic magmas and constraints on Archean geothermal gradients and tectonics. Geology, 3:15-18.

Green, D.H.; Nichols, I.A.; Viljoen, M.; Viljoen, R. 1975. Experimental demonstration of the existence of peridotitic liquids in earliest Archean magmatism. Geology, 3:11-14

Helmstaedt, H.; Padgham, W.A.; Brophy, J.A. 1986. Multiple dikes in Lower Kam Group, Yellowknife greenstone belt: evidence for Archean sea-floor spreading? Geology, 14:562-566.

Herzberg, C. 1992. Depth and degree of melting of komatiites. /. Geophys. Res., 97:4521-4540.

Herzberg, C. 1995. Generation of plume magmas through time: an experimental perspective. Chem. Geol., 126:1-16.
Holm, P.E. 1985. The geochemical fingerprints of different tectonomagmatic environments using hygromagmatophile element abundances of tholeiitic basalts and basaltic andesites. Chem. Geol., 51:303-323.

Huhn, S.R.B. 1992. Geologia, controle estrutural e gênese do depósito aurífero Babaçu, região de Rio Maria sul do Pará Brasília, Universidade de Brasília. 168p. Dissertação de Mestrado $\mathrm{n}^{\text {ü }} 76$. Universidade de Brasília. 1992.

Huhn, S.R.B; MARTINS, L.P.B ; MONTALVÃO, R.M. 1986. Caracterizações petrográficas, texturais e estruturais dos fluxos máfico - ultramáficos do greenstone belt Seringa, sul do Estado do Pará. In: CONGR. BRÁS. GEOL., 34. Goiânia, 1986. Anaw...Goiânia, SBG, v. 2, p. 648-662.

Huhn, S.R.B.; Santos, A.B.S.; Amaral, A.F.; Ledsham, E.J.; Gouveia, J.L.; Martins, L.P.B.; Montalvão, R.M.G.; Costa, V.G. 1988. O terreno "granito - greenstone" da região de Rio Maria - sul do Pará. In: CONGR. BRÁS. GEOL., 35. Belém, 1988. Anais...Belém, SBG, v. 3, p. $1438-1453$.

Irvine, T.N. \& Baragar, W.R.A. 1971. A guide to the chemical classification of the common volcanic rocks. Can. J. Earth Sci., 8:523-545.

Jahn, B.M.; Glikson, A.Y.; Peucat, J.J.; Hickman, A.H. 1981. REE geochemistry and isotopic data of Archean silicic volcanics and granitoids from the Pilbara block, western Australia; implications for the early crustal evolution. Geochim. Cosmochim. Acta, 45:1633-1652.

Jahn, B.M.; Gruau, G.; Glikson, A.Y. 1982. Komatiites of the Onverwacht Group, S. Africa: REE geochemistry, Sm/Nd age and mantle evolution. Contrib. Mineral. Petrol., 80:25-40.

Jensen, L.S. 1976. A new cationic plot for classifying subalkalic volcanic rocks. Ontario Div. Mines, Miscel. Paper, 6: 22p.

Kuno, H. 1968. Differentiation of basaltic magmas. In: HESS, H.H \& POLDERVAART, A. eds. Basalts: The Poldervaart treatise on rocks of basaltic composition, v. 2. Interscience, New York, p. 623-688.

Kusky, T.M \& Kidd, W.S.F. 1992. Remnants of an Archean oceanic plateau, Belingwe greenstone belt, Zimbabwe. Geology, 20:43-46.

Lahaye, Y. \& Arnadt, N. 1996. Alteration of a komatiitic flow from Alexo, Ontario, Canada. J. Petrol., 37:1261-1284.

Maaloe, S. \& Petersen, T.S. 1981. petrogenesis of oceanic andesites. I Geophys. Res., 86:10273-10286.

Macambira, M.J.B. 1992. Chronologic U-Pb, Rb-Sr, K-Ar et croissance de la croüte continentale dans I'Amazonie du sud-est; Exemple de Ia region de Rio Maria, Province de Carajás, Brésil. Montpellier, Université de Montpellier H. 212p. Tese de Doutorado. Universidade de Montpellier H. 1992.

Macambira, M.J.B. \& Lafon, J.M. 1995. Geocronologia da Província Mineral de Carajás; síntese dos dados e novos desafios. Boi. Museu Paraense Emílio Goeldi, Ciências da Terra, 7:263-288.

Macambira, M.J.B. \& Lancelot, J. 1991. História arqueana da região de Rio Maria, SE do Estado do Pará, registrada em zircões detríticos de greenstone belt e de cobertura plataformal. In: SIMP. GEOL. AMAZ., 3. Belém, 1991. Anais..Belém, SBG, p. 59-69.

Machado, N.; Lindenmayer, Z.; Krough, T.E.; Lindenmayer, D. 1991. U-Pb geochronology of Archean magmatism and basement reactivation in the Carajás area, Amazon shield, Brazil. Precamb. Res., 49:329-354.

Martin, H. 1986. Effect of steeper Archaean geothermal gradient on geochemistry of subduction - zone magma. Geology, 14:753-756.

Martin, H. 1994. The Archean grey gneisses and the genesis of continental crust. In: CONDIE, K.C. ed. The Archean crustal evolution. Amsterdam, Elsevier, p. 205-259.

McDonough, W.F. \& Ireland, T.R. 1993. Intraplate origin of komatiites inferred from trace elements in glass inclusions. Nature, 365:432-434.

Miller; G.; Stolper, E.; Ahrens, T.J. 1991. The equation of state of a molten komatiite. 2. Application to komatiite petrogenesis and the Hadean mantle. /. Geophys. Res., 96:11849-11864.

Mullen, E.D. 1983. MnO/TiO2/P2Os: a minor element discrimination for basaltic rocks of oceanic environments and its implication for petrogenesis. Earth Planet. Sci. Lett., 62:53-62.

Nascimento, J.A.S. \& Biagini, D.O. 1988. Conhecimento atual da jazida de ouro de Lagoa Seca, sul do Pará. In: CONGR. BRÁS. GEOL., 35. Belém, 1988. Anexo...Belém, SBG, v. "Província Mineral de Carajás -Litoestratigrafia e Principais Depósitos Minerais", p. 143-157.

Nesbitt, R.W.; Sun, S.S.; Purvis, A.C. 1979. Komatiites: geochemistry and genesis. Can. Mineral., 17:165-186.

Nisbet, E.G. 1982. The tectonic setting and petrogenesis of komatiites. In: ARNDT, N.T. \& NISBET, E.G. eds. Komatiites. London, George Allen \& Unwin, p. 501-520.

Nockolds, S.R. \& Allen, R. 1953. The geochemistry of some igneous rock series, Part I. Geochim. Cosmochim. Acta, 4:105-142.

Ohtani, E. 1989. Partitioning of elements between majorite garnet and melt and implications for petrogenesis of komatiite. Contrib. Mineral. Petrol., 103:263-269. 
Ohtani, E. 1990. Majorite fractionation and genesis of komatiites in the deep mantle. Precamb. Res., 48:195-202.

Oliveira, C.G. 1987 . Mineralizações auríferas da anomalia de Diadema Pará. Brasília, Universidade de Brasília. 93p. Dissertação de Mestrado. Universidade de Brasília. 1987.

Oliveira, C.G. 1993. Interação entre os processos de deformação, metamorfismo e mineralização aurífera durante a evolução da zona de cisalhamento de Diadema, sul do Pará. Brasília, Universidade de

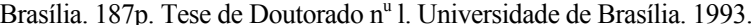

Oliveira, C.G. \& Leonardos, O.H. 1990. Gold mineralization in the Diadema shear belt, Northern Brazil. Econ. Geol, 85:1034-1043.

Oliveira, C.G.; Santos, R.V.; Leonardos, O.H. 1995. Geologia e mineralização aurífera do greenstone belt Sapucaia, sudeste do Pará Boi. Museu Paraense Emílio Goeldi, Ciências da Terra, 7:61-91.

Pearce, J.A. 1976. Statistical analysis of major element patterns in basalt. $J$. Petrol, 17:15-43.

Pearce, J.A. \& Cann, J.R. 1973. Tectonic setting of basic volcanic rocks determined using trace element analysis. Eartn Planet. Sci. Lett., 19:290-300.

Pearce, J.A. \& Norry, MJ. 1979. Petrogenetic implications of Ti, Zr, Y, and $\mathrm{Nb}$ variations in volcanic rocks. Contrib. Mineral. Petrol., 69:33-47.

Pearce, J.A.; Gorman, B.E.; Birkett, T.C. 1977. The relationships between major element chemistry and tectonic environment of basic volcanic rocks. Earth Planet. Sci. Lett., 24:419-426.

Pearce, J.A.; Harris, N.B.W.L; Tindle, A.G. 1984. Trace element discrimination diagrams for the tectonic interpretation of granitic rocks. J. Petrol., 25:956-983.

Pimentel, M.M. \& Machado, N. 1994. Geocronologia U-Pb dos terrenos granito - greenstone de Rio Maria, Pará. In: CONGR. BRAS. GEOL., 38. São Paulo, 1994. Res. Ext...Sao Paulo, SBG, v. 2, p. 390-391.

Rajamani, V.; Shivkumar, K.; Hanson, G.N.; Shirey, S.B. 1985. Geochemistry and petrogenesis of amphibolites, Kolar schist belt, south India: evidence for komatiitic magma derived by low percentages of melting of the mantle. /. Petrol., 26:92-123.

Schulz, K.J. 1982. Magnesian basalts from the Archaean terrains of Minnesota. In: ARNDT, N.T. \& NISBET, E.G. eds. Komatiites. London, George Allen \& Unwin, p. 171-186.

Shaw, D.M. 1970. Trace element fractionation during anatexis. Geochim. Cosmochim. Acta, 34:237-243.

Sorensen, S.S. \& Grosman, J.N. 1989. Enrichment of trace elements in garnet amphibolites from a paleo-subduction zone: Catalina schist, southern California. Geochim. Cosmochim. Acta, 53:3155-3177.

Souza, Z.S. 1994. Geologia epetrogênese do "greenstone belt" Identidade: implicações sobre a evolução geodinâmica do terreno granito "greenstone " de Rio Maria, SE do Pará. Belém, Universidade Federal do Pará. V. 1, 434p.; v. 2, p. 435-625. Tese de Doutorado. Universidade Federal do Pará. Belém. 1994.

Souza, Z.S. \& DALL'AGNOL, R. 1994. Metamorfismo de baixo grau no "greenstone belt" Identidade, região de Xinguara -Rio Maria, SE do Pará. In: SIMP. GEOL. AMAZ., 4. Belém, 1994. Boi. Rés. Êc/7...Belém, SBG, p. 387-390

Souza, Z.S. \& Dall'AgnoI, R. 1995a. Dextral transpression in the Archean Identidade greenstone belt, Carajás Province, Amazonian craton. In: Precambrian'95, Reunion Internationale sur la Tectonique et la Métallogénie dês Ceintures Orogéniques du Précambrien Inférieur et Moyen. Montreal, 1995. Poster Board 12, p. 148.

Souza, Z.S. \& Dall'AgnoI, R. 1995b. Mecanismo de deformação e alojamento de metagranitóides no "greenstone belt" Identidade, SE do Pará. In: SIMP. NAC. EST. TECT., 5. Gramado, 1995. Boi. Rés. Exp...Gramado, SBG, p. 211-212.
Souza, Z.S. \& Dall'Agnol, R. 1995c. Geochemistry of metavolcanic rocks in the Archean greenstone belt of Identidade, SE Pará, Brazil. An. Acad. Bras. Cienc., 76:217-233.

Souza, Z.S. \& Dall'Agnol, R. 1995d. Blastomilonitos xistosos e maciços derivados de rochas ígneas no "greenstone belt" Identidade, SE do Pará. In: SIMP. NAC. EST. TECT., 5. Gramado, 1995. Boi. Rés. £xp...Gramado, SBG, p. 169-170.

Souza, Z.S. \& Dall'Agnol, R. 1996. Química mineral em rochas metavulcânicas do greenstone belt Identidade, SE do Pará: implicacões quanto ao metamorfismo In: SIMP. GEOL. AMAZ., 5. Belém, 1996. Rés. Exp. e Cuia £cc...Belém, SBG, p. 94-96.

Souza, Z.S. \& Dall'Agnol, R.(in press). Vulcanismo cálcio-alcalino mesoarqueano no "greenstone belt" Identidade, sudeste do Pará, Brasil. Geochimica Brasüiensis.

Souza, Z.S.; Dall'Agnol, R.; Althoff, F.J.; Leite, A.A.S.; Barros, C.E.B. 1996. Carajás Mineral Province: geological, geochronological and tectonic contrasts on the Archean evolution of the Rio Maria granite greenstone terrain and the Carajás block. In: SYMP. ARCHEAN TERRANES SOUTH AMER. PLATAFORM., Brasilia, 1996. Ext. Abstr...Brasuiz, SBG, 31-32.

Souza, Z.S.; Lafon, J.M.; Sachet, C.R.; Dall'Agnol, R. 1992a. Geocronologia $\mathrm{Rb} / \mathrm{Sr}$ de metadacitos e diques riolíticos no "greenstone belt" de Identidade, SE do Pará. In: CONOR. BRAS. GEOL., 37. São Paulo, 1992. Bol. Res. Exp...Sao Paulo, SBG, v. 2, p. 184-185.

Souza, Z.S.; Luiz, J.G.; Cruz, J.C.R.; Paiva, R.N. 1992b. Geometria de "greenstone belts" arqueanos da região de Rio Maria (Sudeste do Pará, Brasil) a partir de interpretação gravimétrica. Rev. Bras. Geoc. 22:198-203.

Souza, Z.S.; Medeiros, H.; Althoff, F.J.; Dall'Agnol, R. 1990. Geologia do terreno granito -"greenstone" Arqueano da região de Rio Maria, sudeste do Pará. In: CONOR. BRAS. GEOL., 36. Natal, 1990. Artaw.-.Natal, SBG, v. 6, p. 2913-2928.

Souza, Z.S.; Santos, A.B.S.; Ledsham, E.J.; Martins, L.P.B.; Huhn, S.R.B. Costa, V.G. 1988. Feições geológicas e estruturais do "greenstone belt" Identidade, região de Xinguara - Rio Maria, sul do Pará. In: CONGR. BRÁS. GEOL., 35. Belém, 1988. Anais...Belém, SBG, v. 3, p. $1453-1467$

Stern, R.J.; Morris, J.; Bloomer, S.H.; Hawkins Jr., J.W. 1991. The source of the subduction component in convergent margin magmas: trace element and radiogenic isotope evidence from Eocene boninites, Mariana forearc. Geochim. Cosmochim. Acta, 55:1467-1481.

Storey, M.; Mahoney, J.J.; Kroenke, L.W.; Saunders, A.D. 1991. Are oceanic plateaus sites of komatiite formation? Geology, 19:376-379.

Stormer Jr., J.C. \& Nicholls, J. 1978. XLFRAC: a program for the interactive testing of magmatic differentiation models. Comput. Geosci., 4:143-159.

Tourpin, S.; Gruau, G.; Blais, S.; Fourcade, S. 1991. Resetting of REE, and $\mathrm{Nd}$ and $\mathrm{Sr}$ isotopes during carbonatization of a komatiitic flow from Finland. Chem. Geol., 90:15-29.

Westercamp, D. 1988. Magma generation in the Lesser Antilles: geological constraints. Tectonophysics, 149:145-163.

Wilson, M. 1989. Igneous petrogenesis. London, Academic Press. 466p.

Wood, D.A.; Joron, J.L.;Treuil, M.; Norry, M.; Tarney, J. 1979. Elemental and $\mathrm{Sr}$ isotope variations in basic lavas from Iceland and the surrounding ocean floor. Contrib. Mineral. Petrol., 70:319-339.

MANUSCRITO A879

Recebido em 15 de novembro de 1996

Revisão dos autores em 28 de agosto de 1997 Revisão aceita em 30 de agosto de 1997 